\title{
建築写真を用いた建築における視覚的快適性の評価基準に関する基礎的研究 A STUDY ABOUT THE EVALUATION CRITERIA OF VISUAL COMFORT
ON ARCHITECTURE BY ARCHITECTURAL PICTURES
}

\author{
柴田晃宏*1
}

\section{Akihiro SHIBATA}

\begin{abstract}
This study is intended to clarify the Evaluation Criteria of Visual Comfort(ECVC) on architecture by architectural pictures. At first, we collected examples of architectural pictures that students in architectural department feel visual comfort and the answers why they feel so. 450 keywords are extracted from the answers, and they are classified according to similarity by Affinity Diagram. As the result of classification, 27 groups are defined as ECVC. Then we conducted the impression evaluation experiment with the 27 groups of ECVC and we applied factor analysis and 7 factors are derived from the relationship between 27 groups of ECVC.
\end{abstract}

Keywords: Aesthetics, Picture of Architecture,Education for design,Symmetry 美学, 建築写真, 設計教育, シンメトリー

\section{1 はじめに}

\section{1 研究の背景と目的}

設計教育において、計画、構造、環境配慮など多くの技術的項目 が評価されると同時に、芸術性や美的価值も評価対象とされること が多い。最古の総合的建築書と言われるウィトルウィウス著「建築 に関する十巻の書」において「各種の建物は強さ、用、美の理・立 場が保たれるように造られるべきである」1) と述べられているよう に、古くから「美」は建築の重要項目であり、議論の対象であった。 しかし、設計教育で美しい建築を考えるように指示することは出来 ても、それが何によってもたらされるのかを指示、指導することは 難しい注 1)。これは教育指導者の技量不足の問題もあるかもしれな いが、美的評価基準の曖昧さと未整理に一因がある様に思われる。 また、美的評価は評価される項目の有無だけで決定されるのではな く、程度（レベル）も問題となると思われ、何に心の琴線が触れる のか、どのレベルで触れるのかは個人差注2）2）があり更に判断を複 雑にする。井上 ${ }^{3)}$ や高橋 $\left.{ }^{4}\right)$ らが指摘するように「美」に関する解 明は遅れており、美的評価基準を探求することは設計教育において 意義あると考える。

本研究は「美」を視覚的快適性注 3) と捉え、その評価基準を明ら かにするための基礎的試みである。先ず、視覚的快適性の評価基準 を構成する要素を明らかにし、次いで、各構成要素における程度に よる感受性の差異や各構成要素の組合せによる評価成立条件の検証 を行い、視覚的快適性の評価基準を明らかにしていく。本稿はその 初稿として、建築写真における視覚的快適性を構成する要素の抽出 と整理を行い、得られた構成要素を用いた印象評価実験から評価構
造の一端を明らかにすることを目的とする。

\section{2 既往の研究}

建築における美的評価構造に関する既往研究は余り多くはない。 美的評価を「人間－環境モデル」として捉え、評価グリッド法を用 いた統計的アプローチから分析した研究として、前述の高橋氏らの 一連の研究 4)5) がある。これらはインテリア空間における美的価值 観の傾向分析をおこなった興味深い研究であり，美的評価項目の抽 出を行い、被験者の属性との関係性を分析している点において本研 究と共通している。また、統計的分析を行った研究として、建築の 美的嗜好性と類似性の関係を多次元尺度解析により分析した小野氏 の研究 ${ }^{6)}$ がある。建築作品に対する総合判断として美的価值性だ けで無く、面白さや楽しさといった興味性の寄与を示唆しており、 本研究の視覚的快適性一の視座に共通寸るものである。しかし、高 橋氏らや小野氏の研究では, 心理評価実験の実施上、実験者側が実 験用の写真を用意して、美的評価判断を被験者に問う形式で行われ ている。本稿では、より多様な資料を収集して評価要因を抽出する ために、被験者が美しいと思う写真とその理由の語句を収集し、そ れらに含まれている構成要素の抽出から評価構造の分析を行ってお り、異なるアプローチを採っている。また、本稿では評価要因を回 答語句から抽出しているが、建築を言説から分析を行っている研究 としては、塩崎氏ら 7)899) や北川氏ら 10)1111213) の一連の研究が挙げ られる。塩崎氏らは建築家の思考の枠組みをスケールや対概念など の視点から捉え、北川氏らは語句の持つ多義性から捉えた興味深い 研究であり、語句を扱う上で多くの知見を得た。

美的評価の「美」や「美しさ」についての哲学的、概念的考察
*1 鹿児島大学大学院 准教授. 博士 (工学)
Assoc. Prof., Dept. of Architecture and Architectural Engineering, Faculty of Engineering, Kagoshima University 
を行った研究としては、井上 $\left.{ }^{14)}\right)^{15)}$ 、伊藤 ${ }^{16)}$ 、前述の高橋らの研究 17)18）がある。これらは建築における「美」の在り様を思索している 興味深い研究であり, 評価項目の抽出に関して多くの知見を得た。 また、写真を用いた美的評価の研究として中村らの研究 $\left.{ }^{192} 20\right)$ がある。 これらは写真の属性として輝度やレイアウト比、陰影などから分析 を行っており、写真分析において、建築要素だけではなく、写真技 術による要因も美的評価に寄与することを示唆している。

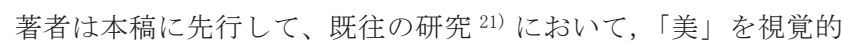
快適性と捉え、建築写真における評価基準を明らかにするため、視 覚的快適要素の抽出を行っている。本稿はそれを基に整理、追加実 験を行い、分析、考察を行うものである。またこれまで，建築家清 家の作品を対象として, 立面構成や比例関係に見られる意匠表現に 関する研究 22) 232 24) を行ってきている。これらの研究では清家の立面 表現における美的側面の考察を行っており, 本研究の着想点ともな っている。本稿は美しいと感じられた建築写真に含まれる構成要素 の抽出を行い、整理することにより、評価構造の一端を明らかにし ようと試みるものである。

\section{3 研究の方法}

本稿では、先ず、建築における視覚的快適性を作り出している要 因を導出するために、建築が写っている写真の中で、被験者が美し (注3) と思う写真注 4) とその理由の回答語句を、建築学科学生を対 象として、景観評価の研究 25)26) 27) で利用されているキャプション 評価法を援用したアンケート調査により収集する。キャプション評 価法では、被験者に写真を撮影してもらうが、本研究では、雑誌や インターネットなどで見られる建築写真の中から、被験者が視覚的 快適性を感じられる写真を提出してもらう形式を採用した。これは、 被験者が実際の風景の中で視覚的快適性を感じたとしても、写真技 術の問題でそれを写真に表現出来ない可能性があるためである。ま た、建築における視覚的快適性と建築写真における視覚的快適性は

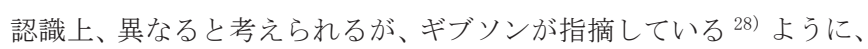
画像の情報には二重性があり、絵画や写真等の画像を見る者には重 層的な経験がなされている。これら 2 つの視覚的経験では、写真の 実在と写真の中にある光景は混同されることなく認識されており、 建築写真から建築における視覚的快適性の要因を抽出することは可 能であると考える。次に 3 章において, アンケート調查の回答から キーワードを抽出し、親和図法的分析により類似グループ毎に整理 を行う。そして 4 章において、3 章の結果を定量的に確認するため、 印象評価実験を行い、また、実験結果の因子分析から視覚的快適性 の評価要因についての関係性を探る。更に、2 章から 4 章での被験 者は建築学科学生であるため、評価構造の一般性について確認する ために、5 章において、因子分析から得られた評価因子を用いた印 象評価実験を、建築学科学生及び一般回答者に対して行い、両者の 差異についての検討を行う。

\section{2 視覚的快適性の構成要因収集のためのアンケート調査}

鹿児島大学建築学科生 25 名（2013 年 1 月）及び、小山工業高等 専門学校生 32 名（2012 年 5 月）の計 57 名を被験者として、建物の 写った美しいと感じる空間の写真 (以下回答写真) と回答写真がど の様に美しいのかを説明したキーワード（以下回答語）を共に提出 して貴うアンケート調查を行った。
アンケート調査では、回答写真は内観、外観どちらでも良いが建 築が主題となっている写真とし、また、どの様に美しいのかを説明 する回答語は文章（センテンス）として表現するのではなく、なる ベく簡潔な語句（ワード）で表現するように、また、1枚の写真に ついて回答語が複数あっても良いとして指示した。また、回答語は 回答写真毎に提出するように指示した。

\section{3 アンケート調査結果の分析}

アンケート調査の結果、171枚の回答写真と 381 語の回答語を得た。 Fig. 1 に回答写真と回答語の一例を示す。回答写真 171 枚のうち内 観が 26 枚、外観が 146 枚であり、外観が多数を占める。また、写真 1 枚当たりの回答語数は最大 6 語、最少 1 語、平均 2.23 語である。

\section{1 回答語の整理}

アンケート調査結果の回答語を通覧してみると、対象や主体を示 寸回答と状態や印象を表す回答があり、また、「明暗のバランス」「際 立つ朱」の様に複数の要因が抽出できる回答語がみられた。2つの 要因が抽出できる回答語は 61 語（要素・対象を示寸回答語が 60 語、 特徴・状態・印象を表す回答語が 62 語)、3 つの要因が抽出できる 回答語は 4 語（要素・対象を示寸回答語が 7 語、特徽・状態・印象 を表す回答語が 5 語）であり、複数の要因が抽出できる回答語を要 因毎に分けると、回答語の総数は 450 となった。

アンケート調査では、回答語を自由記述の形式で収集しているた め、「シンメトリー」「線対称」「左右対称」などの様に、同じような 指摘内容であっても、異なる語句によって表現されているものがみ られる。そこで、筆者および建築学科学生数名の合議制による親和 図法的分析による分類を行い、類似と考えられる回答語を 51 の小グ ループ (以下、視覚的快適要素) と 27 の中グループ（以下、要素グ ループ）に整理した注5)（Table 1）。

視覚的快適要素に含まれる回答語の数に着目すると、色彩 $(41 / 450)$ が最も多く、次いで自然 $(40 / 450)$ 、人工光（夜景） (23/450) と上 位は視覚的な主体を抽出した視覚的快適要素であるが、4位以降は

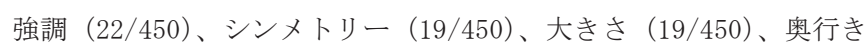
(17/450)、強さ $(12 / 450)$ 、複雑さ $(12 / 450)$ 、調和・バランス $(12 / 450)$ 、 比率 $(12 / 450)$ と続き、配置や構成などの状態を抽出した視覚的 快適要素がみられる。また、視覚的快適要素間の複合をみてみると （Table 2)、上位である色彩、自然、人工光（夜景）は相互に複合が 多く、強調、奥行き、複雑さは色彩と、シンメトリー、調和、反射 は自然との複合が多くみられる。

\section{2 回答写真と視覚的快適要素との比較}

アンケート調査結果の回答写真を通覧してみると、被験者の回答

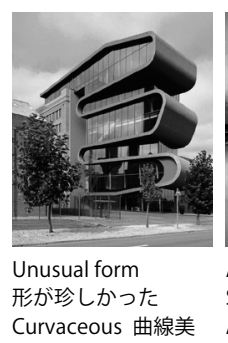

No.A-6

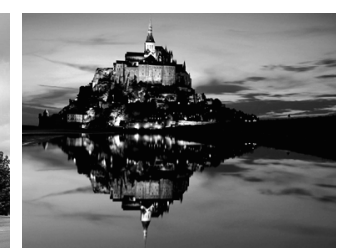

Artifacts like natural 自然物のような人造物 Symmetry by water 水面による対称 Accented by bridge 橋によるアクセント No.A-158

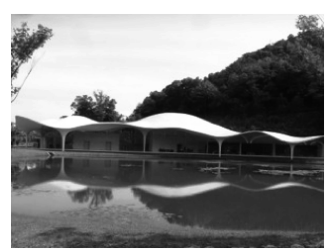

Floating 浮遊 fantastic 幻想的

No.A-135
Fig.1 Example photos and words of the questionnaire for Visual comfort factors 視覚的快適性調査の回答写真と回答語の例 
語には含まれないが、該当すると思われる視覚的快適要素が幾つか みられた。そこで、回答写真毎に各視覚的快適要素が該当するか否 かについて、筆者および建築学科学生数名の合議制による確認を行 った（Table 3)。その結果、146/171 枚において、追加該当となる 視覚的快適要素を確認出来た。前節において回答写真 1 枚当たりの 視覚的快適要素の該当平均は $2.63(450 / 171)$ であるが、本節の確 認による追加を含めると8.53（1459/171）となり、約 6 要素ほど 増加する。教示によって視覚的快適要素の認識を促す可能性がある と考えられる。

\section{4 要素グループによる印象評価実験}

本章では、前章で得られた要素グループを用いた印象評価実験を 行い、視覚的快適性の評価構造の考察を行う。

\section{1 印象評価調査票の作成}

先ず、建築学科学生 15 名を被験者に、前章で得られた要素グルー プ 27 項目を 5 段階評価の設問とした予備実験を行った。評価対象に は 2 章のアンケート調查で得られた回答写真の中から、その他を除 く要素グループ毎に特徽的かつ代表的である写真を 1 枚選出注 6) し た計 26 枚（Fig. 2）の写真を使用した。予備実験から設問項目の内 容を検討し、設問を 25 問に整理した本実験用の印象評価調查票を作 成した (Table 4)。

\section{2 印象評価本実験}

前節で作成した印象評価調査票を用い、建築学科学生計 58 名 (2016 年 4 月）を被験者として、印象評価実験を実施した。実験方法は、 始めに研究主旨と実験内容を説明した後、スライドにより 26 枚の写 真を一枚ずつ投影し、各写真毎に 25 設問について 5 段階で評価し、 全ての写真が終了後、調查票の回収を行った。評価対象は予備実験 で使用した 26 枚の写真を使用した。

実験結果として 26 枚の写真に対する各設問の平均值をTable 5 に 示す。評点 4.0 点以上 $(Q 10 、 Q 14$ に関しては、4.5 点以上と 1.5 点 以下）の質問項目を感知されている要素グループであると捉えると、 写真 1 枚当たりの平均は 5.42 項目（最大 9 項目、最少 2 項目）であ る。これは 2 章でのアンケート調查の結果よりも多く、3-2 で示唆 した教示による認識の向上と推察される。

\section{3 印象評価本実験結果の因子分析}

本節では視覚的快適性の評価構造の考察を行うため、印象評価本 実験結果を用い、印象評価調查票 25 項目の印象軸に対して、探索的 因子分析を行う。因子抽出法は最尤法、回転法は斜交回転のプロマ ックス回転、統計ソフトウェアとして SPAS を使用した。

印象評価本実験結果の Kaiser-Meyer-01kin および Bart1ett の 検定值をTable 6 に示す。Kaiser-Meyer-01kin の標本妥当性の測 度は 0.778 であり、サンプルサイズの妥当性に問題はない。また、 Bartlett の検定は有意水準 0.05 よりも小さく、観測変数の間に関

Table 3 Number of Words Answered with Visual Comfort Factors

\begin{tabular}{|l|l|l|l|l|l|l|l|l|l|l|l|l|l|l|l|l|l|l|l|l|l|l|l|l|l|l|l|}
\hline VCF & F1 & F2 & F3 & F6 & F8 & F11 & F18 & F9 & F20 & F12 & F13 & F22 & F14 & F15 & F23 & F19 & F24 & F21 & F30 & F34 & F35 & F25 & F4 & F37 & F31 & F26 & F27 \\
\hline
\end{tabular} \begin{tabular}{|l|l|l|l|l|l|l|l|l|l|l|l|l|l|l|l|l|l|l|l|l|l|l|l|l|l|l|}
\hline NWA & 41 & 40 & 23 & 22 & 19 & 19 & 17 & 12 & 12 & 12 & 12 & 11 & 11 & 11 & 11 & 10 & 10 & 10 & 9 & 8 & 8 & 7 & 7 & 7 & 6 & 6 \\
\hline
\end{tabular}

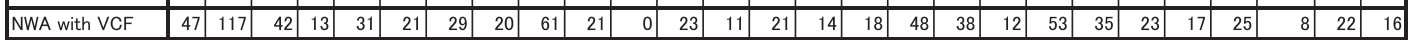
\begin{tabular}{|l|l|l|l|l|l|l|l|l|l|l|l|l|l|l|l|l|l|l|l|l|l|l|l|l|l|l|l|}
\hline Subtotal & 88 & 157 & 65 & 35 & 50 & 40 & 46 & 32 & 73 & 33 & 12 & 34 & 22 & 32 & 25 & 28 & 58 & 48 & 21 & 61 & 43 & 30 & 24 & 32 & 14 & 28 & 22 \\
\hline
\end{tabular}

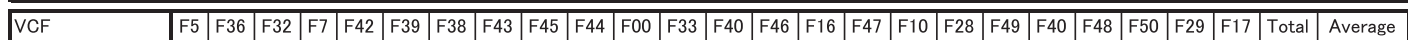

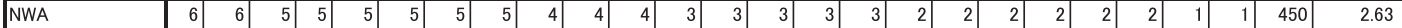

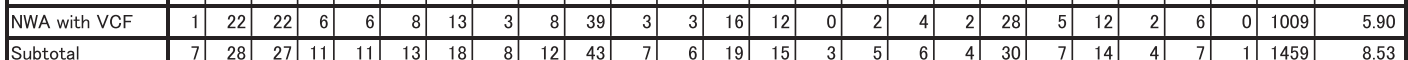

Table 1 Visual Comfort Factor 視覚的快適要素

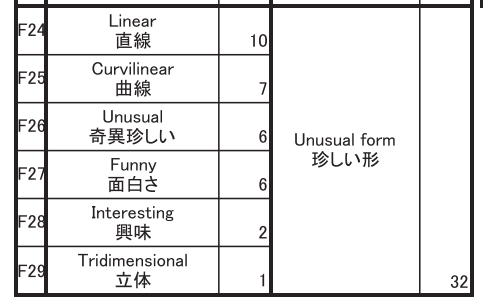

\begin{tabular}{|c|c|c|c|c|c|c|c|c|c|}
\hline & $\begin{array}{c}\mathrm{VCF} \\
\text { 視賞的 } \\
\text { 快適要素 }\end{array}$ & $\begin{array}{l}\text { NWA } \\
\text { 回䉜 } \\
\text { 数 }\end{array}$ & $\begin{array}{l}\text { VCF Group } \\
\text { 要素グループ }\end{array}$ & $\begin{array}{l}\text { NWA } \\
\text { 回䇾 } \\
\text { 語数 } \\
\end{array}$ & & $\begin{array}{c}\text { VCF } \\
\text { 視覚的 } \\
\text { 酸素 }\end{array}$ & $\begin{array}{l}\text { NWA } \\
\text { 回䇾 } \\
\text { 語数 }\end{array}$ & $\begin{array}{l}\text { VCF Group } \\
\text { 要素グループ }\end{array}$ & 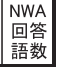 \\
\hline $\mathrm{F} 1$ & $\begin{array}{l}\text { Colorful } \\
\text { 色彩 }\end{array}$ & 41 & $\begin{array}{l}\text { Colorful } \\
\text { 色彩 }\end{array}$ & 41 & $\mathrm{~F} 30$ & $\begin{array}{l}\text { Sanctity } \\
\text { 神聖 }\end{array}$ & 9 & \multirow{4}{*}{$\begin{array}{c}\text { Impression } \\
\text { イメージ }\end{array}$} & \\
\hline $\mathrm{F} 2$ & $\begin{array}{c}\text { Nature } \\
\text { 自然 } \\
\end{array}$ & 40 & $\begin{array}{c}\text { Nature } \\
\text { 自然 } \\
\end{array}$ & 40 & F31 & $\begin{array}{c}\text { Fantasy } \\
\text { 幻想 }\end{array}$ & 6 & & \\
\hline $\mathrm{F} 3$ & $\begin{array}{l}\text { Artificial light } \\
\text { 人工光(夜景) }\end{array}$ & 23 & \multirow{3}{*}{$\begin{array}{c}\text { Contrast of Light } \\
\text { and Dark (CLD) } \\
\text { 明暗 }\end{array}$} & \multirow[b]{3}{*}{36} & F32 & $\begin{array}{l}\text { Foreign } \\
\text { 異国 } \\
\end{array}$ & 5 & & \\
\hline $\mathrm{F} 4$ & $\begin{array}{c}\mathrm{CLD} \\
\text { 光(明暗) }\end{array}$ & & & & F33 & $\begin{array}{c}\text { Floating } \\
\text { 浮遊 }\end{array}$ & 3 & & \\
\hline F5 & $\begin{array}{l}\text { Natural light } \\
\text { 自然光 }\end{array}$ & 6 & & & F34 & $\begin{array}{l}\text { Newness } \\
\text { 新しさ }\end{array}$ & 8 & $\begin{array}{l}\text { Newness } \\
\text { 新しさ }\end{array}$ & \\
\hline F6 & $\begin{array}{c}\text { Emphasis } \\
\text { 強調 }\end{array}$ & 22 & \multirow{2}{*}{$\begin{array}{l}\text { Expression of } \\
\text { Emphasis } \\
\text { 強調表現 }\end{array}$} & \multirow[b]{2}{*}{ 27] } & F35 & $\begin{array}{c}\text { Quietness } \\
\text { 静寂 }\end{array}$ & 8 & \multirow{2}{*}{$\begin{array}{l}\text { Static } \\
\text { 静的 }\end{array}$} & \\
\hline F7 & $\begin{array}{l}\text { Symbol } \\
\text { ジボル }\end{array}$ & 5 & & & $\mathrm{~F} 36$ & $\begin{array}{l}\text { Solace } \\
\text { 癒やL }\end{array}$ & 6 & & \\
\hline F8 & $\begin{array}{l}\text { Greatness } \\
\text { 大きさ }\end{array}$ & 19 & \multirow{3}{*}{$\begin{array}{l}\text { Forceful } \\
\text { 力強さ }\end{array}$} & \multirow[b]{3}{*}{33} & F37 & $\begin{array}{c}\text { Texture } \\
\text { 素材 }\end{array}$ & 7 & \multirow{2}{*}{$\begin{array}{l}\text { Texture } \\
\text { 素材 }\end{array}$} & \\
\hline $\mathrm{F} 9$ & $\begin{array}{l}\text { Strength } \\
\text { 強さ }\end{array}$ & 12 & & & F38 & $\begin{array}{l}\text { Glass } \\
\text { ガラス }\end{array}$ & 5 & & 12 \\
\hline $\mathrm{F} 10$ & $\begin{array}{l}\text { Luxury } \\
\text { 豪華 }\end{array}$ & 2 & & & F39 & $\begin{array}{c}\text { Sequentiality } \\
\text { 連続性 }\end{array}$ & 5 & \multirow{3}{*}{$\begin{array}{c}\text { Repetitive } \\
\text { 反復性 }\end{array}$} & \\
\hline F11 & $\begin{array}{l}\text { Symmetry } \\
\text { シシメトリー }\end{array}$ & 19 & \multirow{7}{*}{$\begin{array}{l}\text { Harmony } \\
\text { 調和 }\end{array}$} & \multirow[b]{7}{*}{69} & F40 & $\begin{array}{l}\text { Regularity } \\
\text { 規則性 }\end{array}$ & 3 & & \\
\hline F12 & $\begin{array}{c}\text { Harmony,Balance } \\
\text { 調和、バランス }\end{array}$ & 12 & & & F41 & $\begin{array}{l}\text { Repetition } \\
\text { 反復 }\end{array}$ & 2 & & + \\
\hline $\mathrm{F} 13$ & $\begin{array}{l}\text { Proportion } \\
\quad \text { 比率 }\end{array}$ & 12 & & & F42 & \begin{tabular}{|c}
$\begin{array}{c}\text { Horizontality } \\
\text { 水平 }\end{array}$ \\
\end{tabular} & 5 & $\begin{array}{c}\begin{array}{c}\text { Horizontality } \\
\text { 水平 }\end{array} \\
\end{array}$ & \\
\hline F14 & $\begin{array}{c}\text { Centrality,Centrality } \\
\text { 中心性、正面性 }\end{array}$ & 11 & & & $\mathrm{~F} 43$ & $\begin{array}{c}\text { Dynamic } \\
\text { 動き }\end{array}$ & 5 & $\begin{array}{c}\text { Dynamic } \\
\text { 動き }\end{array}$ & \\
\hline F15 & $\begin{array}{c}\text { Reflection } \\
\text { 反射 }\end{array}$ & 11 & & & F44 & $\begin{array}{c}\text { Oldness, } \\
\text { History } \\
\text { 古さ、歴史 }\end{array}$ & 4 & $\begin{array}{c}\text { Oldness, } \\
\text { History } \\
\text { 古さ、歴史 }\end{array}$ & \\
\hline F16 & $\begin{array}{c}\text { Functionality } \\
\text { Rationality } \\
\text { 機能性、合理性 }\end{array}$ & 3 & & & F45 & $\begin{array}{c}\text { Transparency } \\
\text { 透明 }\end{array}$ & 4 & $\begin{array}{c}\text { Transparency } \\
\text { 透明 }\end{array}$ & \\
\hline F17 & $\begin{array}{c}\text { Intelligence } \\
\text { 知性 }\end{array}$ & 1 & & & $F 46$ & $\begin{array}{c}\text { Cleanliness } \\
\text { 清潔 }\end{array}$ & 3 & $\begin{array}{c}\text { Cleanliness } \\
\text { 清潔 }\end{array}$ & \\
\hline F18 & $\begin{array}{l}\text { Depth } \\
\text { 奥行き }\end{array}$ & 17] & \multirow{2}{*}{$\begin{array}{c}\text { Depth } \\
\text { Perspective } \\
\text { 奥行き }\end{array}$} & \multirow[b]{2}{*}{27} & F47 & $\begin{array}{c}\text { Structure } \\
\text { 構造 } \\
\end{array}$ & 3 & $\begin{array}{c}\text { Structure } \\
\text { 構造 } \\
\end{array}$ & \\
\hline $\mathrm{F} 19$ & $\begin{array}{c}\text { Photo Composition } \\
\text { 写真の構図 }\end{array}$ & 10 & & & $F 48$ & $\begin{array}{c}\text { Cityscape } \\
\text { 街並み }\end{array}$ & 2 & $\begin{array}{c}\text { Cityscape } \\
\text { 街並み }\end{array}$ & \\
\hline $\mathrm{F} 20$ & $\begin{array}{l}\text { Complex } \\
\text { 複雑さ }\end{array}$ & 12 & \multirow{2}{*}{$\begin{array}{l}\text { Homogeneous } \\
\text { Complex } \\
\text { 均質と複雑さ }\end{array}$} & \multirow[b]{2}{*}{22} & F49 & $\begin{array}{l}\text { Verticality } \\
\text { 垂直 }\end{array}$ & 2 & $\begin{array}{l}\text { Verticality } \\
\text { 垂直 }\end{array}$ & \\
\hline$F 21$ & $\begin{array}{c}\text { Simplex } \\
\text { 単純、シンプル } \\
\end{array}$ & 10 & & & F50 & $\begin{array}{l}\text { Forlorn } \\
\text { 叔れ }\end{array}$ & 2 & $\begin{array}{l}\text { Forlorn } \\
\text { 叔れ }\end{array}$ & \\
\hline $\mathrm{F} 22$ & $\begin{array}{c}\text { Artifact } \\
\text { ᄉI }\end{array}$ & 11 & $\begin{array}{c}\text { Artifact } \\
\text { 人I }\end{array}$ & 11 & Foo & $\begin{array}{l}\text { Others } \\
\text { その他 }\end{array}$ & 4 & $\begin{array}{l}\text { Others } \\
\text { その他 }\end{array}$ & \\
\hline $\mathrm{F} 23$ & $\begin{array}{l}\text { Decoration } \\
\text { Pattern } \\
\text { 装飾、模様 }\end{array}$ & 11 & $\begin{array}{l}\text { Decoration } \\
\text { Pattern } \\
\text { 装飾、模椂 }\end{array}$ & 11 & & $\begin{array}{l}\text { Total } \\
\text { 合計 }\end{array}$ & 450 & $\begin{array}{l}\text { Total } \\
\text { 合計 }\end{array}$ & 45 \\
\hline
\end{tabular}

VCF : Visual Comfort Factor

NWA : Number of Words Answered

Table 2 Combination of Visual Comfort Factors 視覚的快適要素の複合

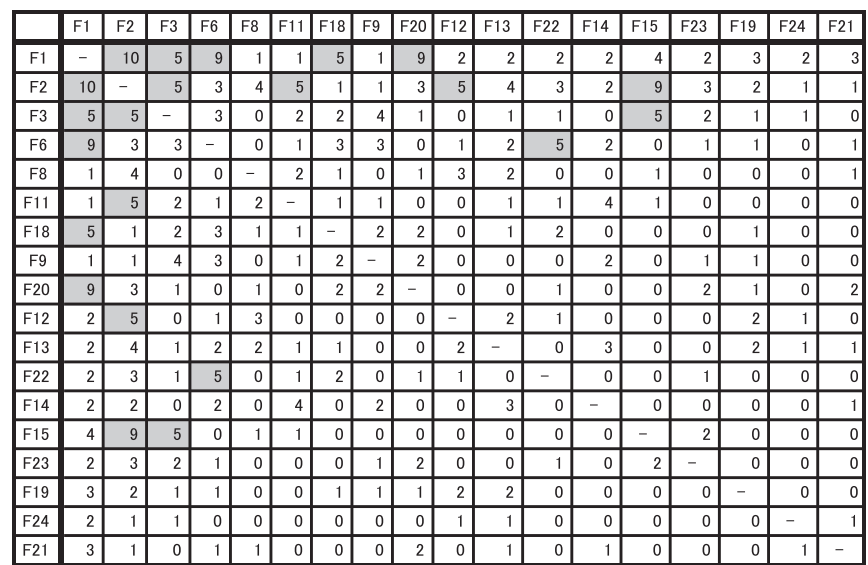
Number of photos is 5 or more 
連があると考えられ、因子分析を行う資料として適切であると判断 した。また、因子のスクリープロット（Fig. 3) から因子数を 7 とし た因子負荷量を Table 7 に示す。

因子 1 は形体に特徵を感じる項目であり、「特徽的な形体」と命名 した。因子 2 は動きと複雑さ関する項目であり、「動静と単複」と 命名した。これらはエントロピーに類するもので共通性を持つので はないかと考える。因子 3 は自然か人工かの区別に関する項目であ り、「自然人工と風合い」と命名した。因子 4 は対比や色彩による強 調に関する項目であり、「対比の強調と力強さ」と命名した。因子 5 は新しさ古さに関する項目であり、「新古」と命名した。因子 6 は清 潔感や透明性に関する項目であり、「清明」と命名した。因子 7 は構 成に関する項目であり、調和や対称性、遠近感などに関係している。 「シュムメトリアの均衡と広がり」と命名した。水平性と垂直性は対 照的な項目であるが、水平性は因子 7、垂直性は因子 3 に含まれる。

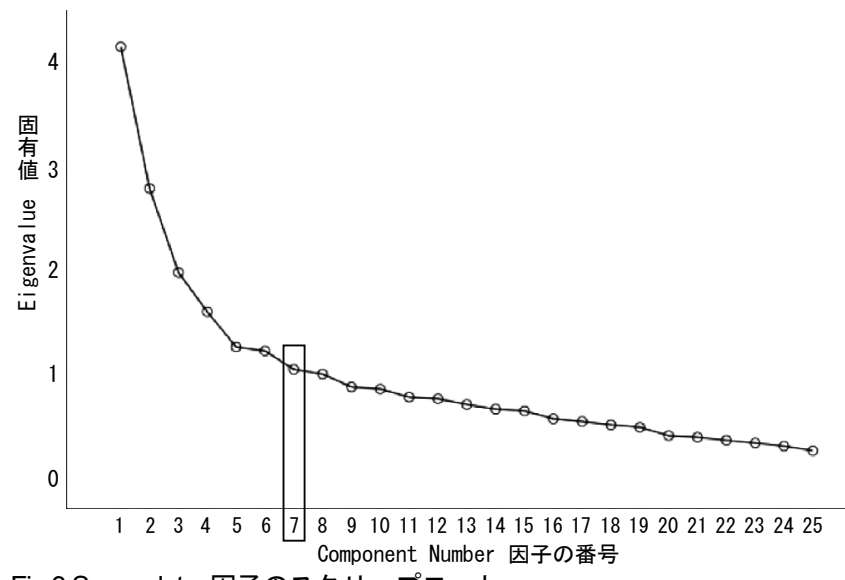

Fig.3 Scree plot＼cjkstart因子のスクリープロット
Table 4 Impression evaluation questionnaires with the Visual comfort factors 視覚的快適因子による印象評価調査票

\begin{tabular}{|c|c|c|}
\hline & $\begin{array}{l}\text { Questionnaires 質問項目 } \\
\end{array}$ & \multirow{4}{*}{ 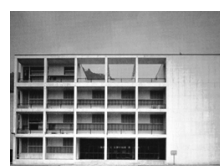 } \\
\hline Q1 & $\begin{array}{l}\text { Do you feel the depth or perspective in this picture? } \\
\text { 奥行きを感じすか。。 }\end{array}$ & \\
\hline Q2 & $\begin{array}{l}\text { Do you evoke any specifici impression from this picture? } \\
\text { 何が具体的なイメージを唤起しますか。。 }\end{array}$ & \\
\hline Q3 & $\begin{array}{l}\text { Do you feel nature in this picture? } \\
\text { 自然を意識しますか。 }\end{array}$ & \\
\hline Q4 & $\begin{array}{l}\text { Do you feel artifacts in this picture? } \\
\text { 人エ物を意識しますか。。 }\end{array}$ & \multirow{2}{*}{ No.B-7 } \\
\hline Q5 & $\begin{array}{l}\text { Do you feel forceful in this picture? } \\
\text { カ強さをを感まますか。 }\end{array}$ & \\
\hline Q6 & $\begin{array}{l}\text { Do you think that color expression is rich in this picture? } \\
\text { 色彩表現が豊かだ思いますか。。 }\end{array}$ & \multirow{6}{*}{ Ain } \\
\hline Q7 & $\begin{array}{l}\text { Do you think it is an unusual form? } \\
\text { 珍しい形たこと思いますか。 }\end{array}$ & \\
\hline Q8 & $\begin{array}{l}\text { Do you feel the contrast of light and dark in this picture? } \\
\text { 明暗を感じますか。 }\end{array}$ & \\
\hline Q9 & $\begin{array}{l}\text { Do you think there is the expression of the emphasis in this picture? } \\
\text { 强調によよる表現がなされていると思いますか。 }\end{array}$ & \\
\hline Q10 & $\begin{array}{l}\text { Whether vou feel homogeneous or complex in this picture? } \\
\text { 均質と複䧴どちらを感しますか。 }\end{array}$ & \\
\hline Q11 & \begin{tabular}{|l|} 
Do you feel verticality in this picture? \\
垂直性を感じますか。
\end{tabular} & \\
\hline Q12 & \begin{tabular}{|l|}
$\begin{array}{l}\text { Do you feel horizontality in this picture? } \\
\text { 水平性を感じすすか。 }\end{array}$ \\
\end{tabular} & No.B-13 \\
\hline Q13 & $\begin{array}{l}\text { Do you feel repetitive in this picture? } \\
\text { 反復性を聋ビますか。 }\end{array}$ & \multirow{13}{*}{ 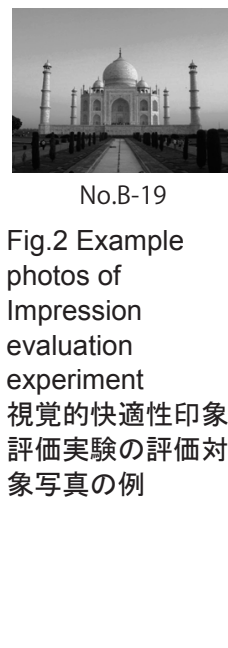 } \\
\hline Q14 & $\begin{array}{l}\text { Whether you think the design is new or aged-old in this picture? } \\
\text { デザインは新しいと思いまます、古いと思いますか。 }\end{array}$ & \\
\hline Q15 & \begin{tabular}{|l} 
Do you think there is cleanliness in this picture? \\
清潈感があると思います。。
\end{tabular} & \\
\hline Q16 & \begin{tabular}{|l} 
Do you think there is a texture in this picture? \\
素材感があると思いますか。
\end{tabular} & \\
\hline Q17 & \begin{tabular}{|l|} 
Do you think there is in harmony in this picture? \\
調和はとれていると思いますか。
\end{tabular} & \\
\hline Q18 & 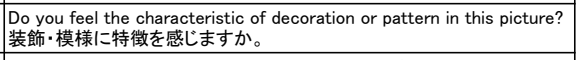 & \\
\hline Q19 & $\begin{array}{l}\text { Do you think there is transparency in this picture? } \\
\text { 透明感があると思いますか。 }\end{array}$ & \\
\hline Q20 & \begin{tabular}{|l|} 
Do you feel history in this picture? \\
歴史を感しますか。
\end{tabular} & \\
\hline Q21 & 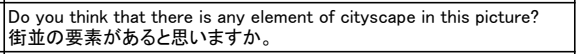 & \\
\hline Q22 & 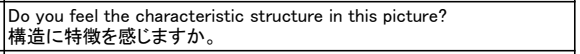 & \\
\hline Q23 & 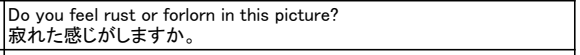 & \\
\hline Q24 & \begin{tabular}{|l} 
Do you feel dynamic expression in this picture? \\
動的な表現かなされれていると思いますか。。
\end{tabular} & \\
\hline & \begin{tabular}{|l} 
Do you feel static expression in this picture? \\
静的な表現がなされていると思いますかか。
\end{tabular} & \\
\hline
\end{tabular}

Table 5 Average of Evalution values of Impression evaluation experiment with the Visual comfort factors 要素グループによる印象評価平均

\begin{tabular}{|c|c|c|c|c|c|c|c|c|c|c|c|c|c|c|c|c|c|c|c|c|c|c|c|c|c|c|c|}
\hline & \multicolumn{26}{|c|}{ Photo Number for Impression evaluation experiment 評価対象写真No. } & \\
\hline & B-1 & B-2 & B-3 & B-4 & B-5 & B-6 & B-7 & B-8 & B-9 & \begin{tabular}{|l|l|l|l}
$B-10$ \\
\end{tabular} & 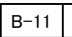 & 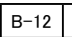 & B-13 & \begin{tabular}{|l|l|l|l} 
B-14 \\
\end{tabular} & 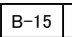 & 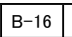 & B-17 & B-18 & B-19 & B-20 & B-21 & $\mathrm{B}-22$ & B-23 & B-24 & B-25 & B-26 & \\
\hline Q1 & 3.91 & 3.45 & 3.66 & 4.78 & 4.22 & 1.91 & 2.90 & 4.00 & 4.90 & 3.05 & 3.26 & 3.59 & 3.71 & 3.71 & 4.07 & 3.79 & 3.26 & 4.09 & 3.52 & 4.16 & 4.60 & 2.59 & 3.79 & 3.02 & 4.07 & 4.67 & \\
\hline Q2 & 3.41 & 3.84 & 4.43 & 3.14 & 4.07 & 2.03 & 2.69 & 3.60 & 3.67 & \begin{tabular}{l|l}
4.16 \\
\end{tabular} & 3.26 & 3.90 & 3.19 & 3.84 & 3.12 & 3.36 & 3.12 & 3.09 & 3.98 & 3.09 & 2.69 & 3.16 & 2.91 & 3.28 & 3.93 & 3.05 & \\
\hline Q3 & 1.97 & 4.71 & 1.33 & 3.34 & \begin{tabular}{|l|}
2.74 \\
\end{tabular} & 1.95 & 1.47 & 3.67 & 4.67 & 4.17 & 1.95 & $\begin{array}{l}4.33 \\
\end{array}$ & 1.65 & 1.16 & \begin{tabular}{|l|l|}
4.34 \\
\end{tabular} & 3.25 & 1.24 & 2.09 & \begin{tabular}{|l|l|}
2.17 \\
\end{tabular} & 4.33 & 1.38 & 1.14 & 1.26 & 2.78 & 1.98 & 1.90 & \\
\hline Q4 & 4.49 & 2.97 & 4.97 & 3.48 & 3.41 & 4.60 & 4.66 & 4.50 & 2.55 & 4.38 & \begin{tabular}{|l|l}
4.59 \\
\end{tabular} & \begin{tabular}{|l|}
4.12 \\
\end{tabular} & 4.55 & 4.91 & 3.24 & 4.41 & 4.86 & 3.97 & \begin{tabular}{l|l}
4.66 \\
\end{tabular} & 3.47 & 4.53 & 4.95 & 4.66 & 4.17 & 4.40 & 4.53 & \\
\hline Q5 & 4.40 & 3.05 & 4.79 & 2.21 & \begin{tabular}{|l|}
2.14 \\
\end{tabular} & 3.09 & 3.28 & 4.09 & 2.98 & 4.45 & 4.34 & \begin{tabular}{l|l}
4.16 \\
\end{tabular} & 3.50 & 3.90 & \begin{tabular}{|l|l}
3.19 \\
\end{tabular} & 4.22 & 4.41 & 2.79 & \begin{tabular}{ll|}
4.66 \\
\end{tabular} & \begin{tabular}{|l|}
3.03 \\
\end{tabular} & 3.00 & 3.98 & 4.43 & 3.41 & 3.05 & 4.21 & \\
\hline Q6 & 3.18 & 2.41 & 2.52 & 3.09 & \begin{tabular}{|l|}
2.05 \\
\end{tabular} & 2.17 & 2.00 & 2.62 & $\begin{array}{l}3.36 \\
\end{array}$ & 4.24 & 4.02 & 3.14 & 82 & 3.59 & 2.91 & 3.90 & 3.19 & 3.19 & 2.74 & 2.98 & 1.98 & 2.90 & 3.00 & 3.22 & 2.40 & 3.69 & \\
\hline Q7 & 2.90 & 1.64 & 3.57 & 3.64 & 1.66 & 3.03 & 3.10 & 5.00 & 2.02 & 2.95 & 4.12 & 3.60 & 3.19 & 2.69 & 3.29 & 3.41 & 4.90 & 2.91 & 4.33 & 4.50 & 3.69 & 4.09 & 4.83 & 2.59 & 3.86 & 3.16 & \\
\hline Q8 & 4.72 & 1.95 & 4.02 & 4.29 & 2.24 & 2.71 & 2.79 & 4.17 & \begin{tabular}{|c|}
3.88 \\
\end{tabular} & 2.88 & 4.57 & \begin{tabular}{l|}
2.28 \\
\end{tabular} & 2.60 & \begin{tabular}{|c|}
3.47 \\
\end{tabular} & \begin{tabular}{l|l}
3.45 \\
\end{tabular} & \begin{tabular}{|c|}
3.98 \\
\end{tabular} & 3.45 & 3.52 & 2.22 & 2.74 & 2.62 & 4.31 & 4.26 & 3.55 & 4.31 & 4.5 & \\
\hline Q9 & 4.26 & 2.66 & 3.67 & 3.36 & 2.90 & 3.86 & 2.41 & 4.34 & \begin{tabular}{|c|}
3.17 \\
\end{tabular} & \begin{tabular}{|l|}
4.57 \\
\end{tabular} & 4.28 & \begin{tabular}{l|l|}
3.64 \\
\end{tabular} & 3.00 & 3.98 & \begin{tabular}{|l|}
3.47 \\
\end{tabular} & \begin{tabular}{|l|}
3.95 \\
\end{tabular} & 4.12 & 2.82 & 3.97 & \begin{tabular}{|l|}
3.03 \\
\end{tabular} & 2.56 & 3.36 & 4.40 & 3.16 & 3.93 & 3.91 & \\
\hline Q10 & 3.52 & 3.76 & 1.84 & 3.91 & \begin{tabular}{ll|}
4.16 \\
\end{tabular} & 4.67 & \begin{tabular}{ll|}
4.18 \\
\end{tabular} & 2.23 & 4.28 & 3.41 & 2.45 & \begin{tabular}{l|}
2.26 \\
\end{tabular} & 2.24 & 2.47 & \begin{tabular}{l|l}
3.05 \\
\end{tabular} & \begin{tabular}{|l|}
2.76 \\
\end{tabular} & 1.24 & 4.48 & 4.10 & 2.97 & 3.86 & 1.33 & 3.19 & 3.83 & 4.12 & 4.12 & \\
\hline Q11 & 4.16 & 3.57 & 4.07 & 3.29 & 2.97 & 4.22 & $\begin{array}{l}4.17 \\
\end{array}$ & 1.54 & 2.21 & 3.29 & 2.55 & $\begin{array}{l}4.31 \\
\end{array}$ & 3.16 & 4.57 & 3.40 & 3.78 & 2.64 & 3.57 & 3.95 & 3.19 & 2.91 & 3.45 & 4.48 & 3.60 & 3.66 & 3.30 & \\
\hline Q12 & 3.05 & 3.26 & 2.31 & 3.97 & $\begin{array}{l}3.79 \\
\end{array}$ & 2.95 & 4.14 & 2.17 & 4.55 & 3.00 & \begin{tabular}{l|l}
3.50 \\
\end{tabular} & \begin{tabular}{|l|l|}
2.17 \\
\end{tabular} & 2.50 & 2.22 & \begin{tabular}{l|l}
2.52 \\
\end{tabular} & 3.74 & 2.34 & 2.50 & \begin{tabular}{|l|}
3.53 \\
\end{tabular} & 1.95 & 2.90 & 2.47 & 2.67 & 3.69 & 3.45 & 4.22 & \\
\hline Q13 & $\begin{array}{ll}3.12 \\
\end{array}$ & 2.02 & 2.29 & $\begin{array}{l}3.34 \\
\end{array}$ & \begin{tabular}{|l|}
3.17 \\
\end{tabular} & 2. & 3.97 & \begin{tabular}{ll|}
2.48 \\
\end{tabular} & 2.97 & 2.57 & \begin{tabular}{l|l}
3.22 \\
\end{tabular} & 2. & 67 & 2.93 & \begin{tabular}{l|l}
26 \\
\end{tabular} & 2.81 & 41 & 3.26 & 59 & 79 & 14 & 2.97 & 2.19 & 2.88 & 62 & 4.00 & \\
\hline Q14 & 2.14 & 1.79 & 3.48 & 4.31 & 1.17 & 3.83 & 3.34 & 4.90 & 2.90 & 2.02 & 2.81 & \begin{tabular}{|l|}
2.29 \\
\end{tabular} & 2.55 & 3.53 & $\begin{array}{ll}1.79 \\
\end{array}$ & 2.62 & 4.93 & 2.55 & 2.71 & 4.22 & 3.29 & 3.93 & 4.62 & 2.45 & 4.09 & 3.41 & \\
\hline Q15 & 3.90 & 3.10 & 2.60 & 4.57 & 2.33 & 4.41 & 3.64 & 3.83 & 3.76 & 3.31 & \begin{tabular}{l|l|}
3.34 \\
\end{tabular} & \begin{tabular}{|l|}
3.50 \\
\end{tabular} & 1.97 & 3.41 & \begin{tabular}{ll|}
1.76 \\
\end{tabular} & \begin{tabular}{|c|}
3.62 \\
\end{tabular} & 3.28 & 4.07 & 3.62 & \begin{tabular}{ll|}
3.74 \\
\end{tabular} & \begin{tabular}{|l|}
3.83 \\
\end{tabular} & 2.26 & 3.21 & \begin{tabular}{ll|}
3.64 \\
\end{tabular} & 4.19 & 3.57 & \\
\hline Q16 & 2.93 & 3.00 & 3.71 & 3.59 & \begin{tabular}{|l|}
4.43 \\
\end{tabular} & 3.26 & 2.74 & 3.19 & 3.62 & 3.78 & 2.62 & \begin{tabular}{|c|}
3.07 \\
\end{tabular} & 3.03 & 2.38 & 3.71 & \begin{tabular}{|l|}
3.39 \\
\end{tabular} & 3.16 & 3.71 & 3.02 & \begin{tabular}{l|l|}
4.24 \\
\end{tabular} & 3.02 & 3.31 & 2.24 & 2.97 & 3.31 & 3.00 & \\
\hline Q17 & 3.90 & 4.19 & 3.16 & 4.28 & 4.09 & 2.52 & 3.29 & 3.22 & 4.41 & 3.26 & \begin{tabular}{|l|}
3.84 \\
\end{tabular} & \begin{tabular}{|l|}
4.03 \\
\end{tabular} & 3.47 & \begin{tabular}{|c|}
3.47 \\
\end{tabular} & \begin{tabular}{|l|}
3.61 \\
\end{tabular} & \begin{tabular}{|l|l|}
4.12 \\
\end{tabular} & 2.62 & 3.93 & 3.86 & 3.83 & 3.81 & 2.59 & 3.16 & 4.14 & 3.81 & 3.89 & \\
\hline Q18 & $\begin{array}{l}3.86 \\
\end{array}$ & 1.90 & 3.00 & 3.95 & 2.52 & 2.67 & 2.75 & 3.90 & 2.24 & 4.28 & \begin{tabular}{l|l|}
4.05 \\
\end{tabular} & 4.09 & 3.22 & \begin{tabular}{|l|l|}
3.14 \\
\end{tabular} & 2.60 & \begin{tabular}{|l|}
3.83 \\
\end{tabular} & 4.41 & 3.03 & 4.21 & $\begin{array}{l}3.65 \\
\end{array}$ & 3.60 & 3.41 & 3.91 & 3.71 & \begin{tabular}{|c|}
3.71 \\
\end{tabular} & 3.55 & \\
\hline Q19 & 3.10 & 2.64 & 1.98 & 4.28 & 1.64 & 3.40 & 2.95 & 3.21 & 3.07 & 2.40 & 2.90 & \begin{tabular}{|l|}
2.66 \\
\end{tabular} & 1.64 & 2.81 & \begin{tabular}{|l|}
1.67 \\
\end{tabular} & \begin{tabular}{|l|}
2.93 \\
\end{tabular} & 3.30 & 3.74 & 2.72 & 3.52 & 3.14 & 2.14 & 2.74 & 2.79 & 3.50 & 2.88 & \\
\hline Q20 & \begin{tabular}{|l|l}
4.16 \\
\end{tabular} & 3.91 & \begin{tabular}{|l|}
2.43 \\
\end{tabular} & 2.09 & 4.72 & 1.38 & 2.00 & 1.60 & \begin{tabular}{|l|}
2.67 \\
\end{tabular} & 4.66 & \begin{tabular}{l|l}
4.16 \\
\end{tabular} & \begin{tabular}{|l|}
4.45 \\
\end{tabular} & 3.64 & 2.66 & $\begin{array}{ll}4.29 \\
\end{array}$ & \begin{tabular}{|l|l|}
4.47 \\
\end{tabular} & 1.31 & 3.56 & \begin{tabular}{|l|}
4.38 \\
\end{tabular} & 2.09 & 3.19 & 1.71 & 1.60 & 4.19 & 2.64 & 3.09 & \\
\hline Q21 & 3.76 & 1.57 & 1.34 & 2.83 & 4.31 & 2.07 & 2.00 & 1.66 & 2.17 & 1.90 & 2.83 & \begin{tabular}{|l|}
2.45 \\
\end{tabular} & 4.52 & 4.07 & 2.16 & 2.67 & 1.55 & 4.03 & 2.14 & 1.64 & 2.90 & 1.60 & 3.10 & 3.83 & 1.69 & 3.24 & \\
\hline Q22 & 3.64 & 2.14 & 3.88 & 3.55 & 2.55 & 3.16 & 3.40 & 4.86 & 2.05 & 3.38 & 4.10 & \begin{tabular}{|l|}
3.93 \\
\end{tabular} & 2.95 & 3.34 & \begin{tabular}{l|l}
2.68 \\
\end{tabular} & \begin{tabular}{|c|}
3.93 \\
\end{tabular} & 4.74 & 2.78 & \begin{tabular}{|l|}
4.33 \\
\end{tabular} & 4.22 & 3.74 & 3.98 & 4.34 & 3.34 & 3.61 & 3.24 & \\
\hline Q23 & 2.86 & 4.24 & 2.16 & 2.55 & 4.45 & 2.59 & 2.97 & 2.34 & 3.24 & 2.19 & $\begin{array}{ll}2.26 \\
\end{array}$ & \begin{tabular}{|l|}
2.90 \\
\end{tabular} & 2.36 & 1.90 & \begin{tabular}{l|l}
4.26 \\
\end{tabular} & \begin{tabular}{|l|}
2.33 \\
\end{tabular} & 1.38 & \begin{tabular}{|l|}
2.91 \\
\end{tabular} & \begin{tabular}{|l|}
2.21 \\
\end{tabular} & 1.81 & \begin{tabular}{l|l}
2.38 \\
\end{tabular} & 2.07 & 1.69 & 2.52 & 2.60 & 2.29 & \\
\hline Q24 & 2.0 & 2.79 & \begin{tabular}{l|l}
3.78 \\
\end{tabular} & 1.88 & 1.59 & 1.76 & 1.81 & 4.24 & 2.33 & 2.36 & \begin{tabular}{l|l}
3.09 \\
\end{tabular} & \begin{tabular}{|l|}
2.36 \\
\end{tabular} & 3.45 & \begin{tabular}{|l|}
3.03 \\
\end{tabular} & \begin{tabular}{c|}
1.97 \\
\end{tabular} & \begin{tabular}{|l|}
2.72 \\
\end{tabular} & 4.29 & 2.02 & \begin{tabular}{|l|}
2.62 \\
\end{tabular} & 3.59 & 2.50 & \begin{tabular}{|l|l} 
\\
\end{tabular} & 3.34 & 2.21 & 1.69 & 2.48 & \\
\hline Q25 & 4. & 3.93 & 2.31 & 4.43 & 4.19 & 3.95 & 3.90 & 2.76 & 4.09 & 3.78 & 3.29 & \begin{tabular}{|l|l|}
4.00 \\
\end{tabular} & 2.28 & 2.93 & 4.05 & \begin{tabular}{|l|}
3.74 \\
\end{tabular} & 1.86 & 4.09 & 3.69 & 2.90 & 3.48 & 1.95 & 2.93 & 3.88 & \begin{tabular}{|l|}
4.17 \\
\end{tabular} & 3.72 & 均 \\
\hline cells & 7 & 3 & 5 & 6 & 9 & 4 & 3 & 8 & 5 & 8 & 9 & 7 & 2 & 3 & 5 & 4 & 9 & 4 & 6 & 5 & 3 & 5 & 8 & 3 & 5 & 5 & 5.42 \\
\hline
\end{tabular}

Evalution value is 4.0 or more ( 4.5 or more or less than 1.5 on Q10,Q14) 
水平性は対称性などの構成を想起させ、垂直性は人工物などを想起 させるのではないかと推察する。

\section{5 視覚的快適因子による印象評価実験}

前章までのアンケート調查や印象評価実験は建築学科学生を対象 に行っている。そこで本章では、前章の因子分析で得られた 7 因子 （以下、視覚的快適因子）の一般性を検証寸るため、視覚的快適因子 を用いて、建築学科学生および一般回答者を対象とした印象評価実 験を行い、両者の比較考察を行う。

\section{1 視覚的快適因子による印象評価調査票の作成}

視覚的快適因子を用いた印象評価調查票の作成寸るにあたり、前 章と同様に建築学科学生 8 名による予備調査を計 2 回行った。

予備調查において、「動静と単複」の設問は 1 つの設問では判断 し難いとの意見が多かったため、「動静」と「単複」の設問を分 け、評価対象の建築写真を「美しいと感じるか」の設問を加えた計 9 設問（Table 8）を 5 段階評価とした印象評価調查票を作成した。 評価対象は建築雑誌や建築写真集から年代及び和洋の偏りが出ない よう 24 枚の建築写真注 7) を選出した（Fig. 4)。また、一般回答者に 対する調査実験では性別、年齢、職業の回答者属性に関する設問も 追加した。

\section{2 視覚的快適因子による印象評価実験}

前節で作成した印象評価調査票を用い、建築学科学生計 55 名 (2016 年 11 月）を対象に視覚的快適因子による印象評価実験を実施した。 実験方法は、始めに研究主旨と実験内容を説明した後、スライドに

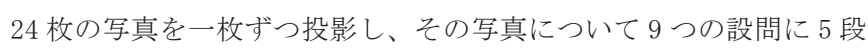
階で評価する方法を採った。次に、一般回答者計 48 名（2016 年 11 月〜 12 月) を対象に、視覚的快適因子による印象評価実験を実施 した。調查方法は、研究主旨と実験内容を説明した後、A6 サイズの 評価対象写真と実験内容を記載した用紙と調查票を配布し、各自で 回答してもらい、後日回収する方法を採った。一般回答者の属性を Table 9 に示す。

実験結果として 24 枚の写真に対する各設問の平均值を Table 10 (建築学科学生) および Table 11 (一般回答者) に示す。概补、建 築学科学生と一般回答者とで $\mathrm{Q} 9$ の平均值が 1.0 以上（美しいと感じ られている) の評価対象は一致している。また、建築学科学生と一 般回答者との間で平均值の差は概ね 0.2 程度であり大きくはない。 建築学科学生と一般回答者の平均值の $\mathrm{t}$ 検定を行うと（Table 12）、 平均值の有意差がみられる評価対象の多い設問は $Q 4 、 Q 7 、 Q 9$ である。 Q4 は「自然人工と風合い」Q7 は「清明さ」に関する設問、Q9 は「美 しさを感じるか」の設問であり、建築教育がこれらの感受性に影響 する可能性が推察される。

\section{3 視覚的快適因子と評価の関係}

Table 10 及びTable 11 をみてみると、視覚的快適因子の評価の 高いものが多い評価対象は美しいと感じられる傾向が窥えるが、必 ずしも一致はしていない。そこで、Q9 の平均值が 1.0 以上（美しい と感じられている）である評価対象の各視覚的快適因子の評価值を みてみると (Fig. 5)、建築学科学生と一般回答者ともに、視覚的快 適因子「対比の強調と力強さ」、「清明さ」、「シュムメトリアの均衡 と広がり」、「動静」、「特徵的な形体」、「自然人工と風合い」の評価 值が高く、視覚的快適因子「単複」、「新古」の評価值が低い。逆に、
Table $6 \mathrm{KMO}$ and Bartlett's test

Kaiser-Meyer-Olkin および Bartlett の検定值

\begin{tabular}{|l|l|r|}
\hline $\begin{array}{l}\text { Kaiser-Meyer-Olkin Measure of Sampling Adequad } \\
\text { Kaiser-Meyer-Olkin の標本妥当性の測度 }\end{array}$ & 0.778 \\
\hline \multirow{2}{*}{$\begin{array}{l}\text { Bartlett's test of } \\
\text { sphericity } \\
\text { Bartlett の球面性検定 }\end{array}$} & $\begin{array}{l}\text { Approx.Chi-Square } \\
\text { 近似カイ 2 乗 }\end{array}$ & $\begin{array}{l}\text { Degree of Freedom } \\
\text { 自由度 }\end{array}$ \\
\cline { 2 - 3 } & $\begin{array}{l}\text { Significance } \\
\text { probability } \\
\text { 有意確率 }\end{array}$ & 300.00 \\
\hline
\end{tabular}

Table 7 Rotated Factor Matrix 回転後の因子負荷量

\begin{tabular}{|c|c|c|c|c|c|c|c|}
\hline & \begin{tabular}{|c|} 
Factor 1 \\
因子1 \\
Distinguishing \\
form \\
特徵的 \\
な形体 \\
\end{tabular} & $\begin{array}{c}\text { Factor 2 } \\
\text { 因子2 } \\
\text { Homogeneous } \\
\text {-Complexity, } \\
\text { Static-Dynamism } \\
\text { 動静と } \\
\text { 单複 } \\
\end{array}$ & \begin{tabular}{|c|} 
Factor 3 \\
因子3 \\
Nature- \\
Artifact \\
Texture \\
自然人工と \\
風合い \\
\end{tabular} & $\begin{array}{c}\text { Factor } 4 \\
\text { 因子4 } \\
\text { Emphasis } \\
\text { by contrast } \\
\text { Forceful } \\
\text { 対比の強調 } \\
\text { と力強さ } \\
\end{array}$ & $\begin{array}{c}\text { Factor 5 } \\
\text { 因子5 } \\
\text { New } \\
\text { Age-Old } \\
\text { 新古 }\end{array}$ & \begin{tabular}{|c|} 
Factor 6 \\
因子6 \\
Cleanliness \\
Clarity \\
清明
\end{tabular} & $\begin{array}{c}\text { Factor } 7 \\
\text { 因子7 } \\
\text { Repetition } \\
\text { Symmetry } \\
\text { Harmony } \\
\text { シムメリアリ } \\
\text { 均衡と広がり } \\
\end{array}$ \\
\hline Q22 & 0.846 & -0.003 & 0.005 & -0.088 & 0.007 & 0.015 & 0.062 \\
\hline Q7 & 0.766 & 0.059 & 0.035 & -0.022 & -0.215 & -0.096 & -0.027 \\
\hline Q18 & 0.722 & 0.027 & 0.026 & 0.038 & 0.12 & 0.026 & 0.128 \\
\hline Q25 & 0.084 & 0.928 & 0.024 & 0.159 & 0.022 & -0.008 & -0.053 \\
\hline Q24 & 0.01 & -0.735 & 0.141 & 0.152 & -0.045 & -0.002 & -0.021 \\
\hline Q10 & -0.109 & 0.302 & 0.035 & -0.134 & 0.002 & 0.187 & 0.195 \\
\hline Q3 & 0.055 & 0.027 & 0.849 & 0.031 & 0.113 & 0.061 & -0.261 \\
\hline Q4 & \begin{tabular}{l|l|}
0.162 \\
\end{tabular} & 0.035 & -0.629 & 0.091 & 0.08 & 0.06 & -0.048 \\
\hline Q16 & 0.117 & -0.064 & 0.271 & -0.084 & 0.071 & 0.005 & 0.134 \\
\hline Q11 & -0.014 & 0.085 & -0.229 & 0.132 & 0.108 & 0.045 & 0.133 \\
\hline Q8 & -0.137 & 0.075 & -0.067 & 0.615 & -0.251 & -0.077 & 0.068 \\
\hline Q9 & 0.071 & 0.09 & -0.069 & 0.606 & 0.015 & 0.039 & -0.164 \\
\hline Q6 & -0.043 & -0.065 & 0.073 & 0.539 & 0.051 & -0.001 & 0.072 \\
\hline Q5 & 0.153 & -0.115 & -0.156 & 0.442 & 0.224 & 0.045 & -0.134 \\
\hline Q20 & 0.096 & 0.033 & 0.053 & 0.021 & 0.775 & 0.004 & 0.113 \\
\hline Q14 & 0.224 & -0.044 & 0.009 & 0.073 & -0.686 & 0.091 & -0.019 \\
\hline Q23 & -0.046 & 0.223 & 0.199 & -0.111 & 0.231 & -0.153 & -0.063 \\
\hline Q2 & 0.038 & -0.132 & 0.188 & 0.185 & 0.21 & 0.003 & 0.075 \\
\hline Q15 & -0.026 & -0.019 & -0.027 & -0.08 & 0.018 & 1.055 & -0.059 \\
\hline Q19 & -0.002 & 0.07 & 0.063 & 0.133 & -0.163 & 0.447 & 0.036 \\
\hline Q21 & -0.031 & -0.033 & -0.119 & 0.048 & 0.189 & -0.086 & 0.467 \\
\hline Q13 & 0.161 & -0.038 & -0.071 & -0.18 & 0.027 & 0.006 & 0.372 \\
\hline Q17 & -0.013 & 0.049 & 0.282 & 0.155 & 0.067 & 0.111 & 0.346 \\
\hline Q12 & 0.003 & 0.114 & 0.068 & 0.08 & -0.01 & -0.007 & 0.314 \\
\hline Q1 & 0.09 & -0.051 & 0.251 & 0.096 & -0.077 & -0.018 & 0.309 \\
\hline
\end{tabular}

Table 8 Impression evaluation questionnaires with the Visual comfort factors 視覚的快適因子による印象評価調査票

\section{Questionnaires 質問項目}

Do you feel the distinguishing form in this architectural picture? Q1 形体に特徵を感じますか。

Do you feel homogeneous expression

Q 2 complex expression in this architectural picture?

2 均質な表現がなされていると思いますか、

あるいは複雑な表現がなされていると思いますか。

Do you feel static expression

or dynamic expression in this architectural picture?

Q3 静的な表現がなされていると思いますか、

あるいは動的な表現がなされていると思いますか。

Do you feel nature or texture in this architectural picture?

Q4 自然や風合いを感じますか。

Do you feel the emphasis

Q5 or forceful of the contrast in this architectural picture? 対比の強調や力強さを感じますか。

Do you feel new or aged-old in this architectural picture?

Q6 \begin{tabular}{l} 
新しさを感じますか、あるいは古さを感じますか。 \\
\hline
\end{tabular}

Q7 Do you feel cleanliness or clarity in this architectural picture? Q7 清純さを感じますか。

Do you feel repetitiveness, symmetry

Q8 or harmony in this architectural picture? 反復性や対称性、調和を感じますか。

Q9 Do you think this architectural picture is beautiful? この建築写真は美しいと思いますか。 
Q9 の平均值が 0 以下（美しいと感じられていない）である評価対象 の各視覚的快適因子の評価值をみてみると、視覚的快適因子「単複」、

「動静」の評価值が高い。また、「シュムメトリアの均衡と広がり」 がやや高く、「新古」がやや低い傾向にあるが、その他の視覚的快適 因子の評価值は概ね 0.0 に近い值である。これらから、「対比の強調 と力強さ」「清明さ」「シュムメトリアの均衡と広がり」「特徴的な形 体」「自然人工と風合い」「複雑さ」があることは視覚的快適性評価 を高くする可能性があるが、「静的」「古さ」は視覚的快適性評価を 高くする場合と低くする場合があることが推察され、また、各視覚 的快適因子の評価值が 0.0 に近くなると視覚的快適性評価が低くな る可能性があると考えられる。

\section{4 視覚的快適因子の相関分析}

Fig. 5 のレーダーチャートの形状と視覚的快適性評価の関係から、 視覚的快適因子同士に関連が窅える。そこで本節では視覚的快適因 子同士の相関関係についての分析を行う。

建築学科学生と一般回答者の各視覚的快適因子同士の相関係数を それぞれ Table 13 (建築学科学生) およびTable 14（一般回答者） に示す。建築学科学生と一般回答者ともに、「対比の強調と力強さ」 と「シュムメトリアの均衡と広がり」「特徴的な形体」「シュムメト リアの均衡と広がり」と「古さ」、「複雑さ」と「動的」「特徴的な形 体」「動的」と「新しさ」「特徴的な形体」「古さ」と「自然人工と
風合い」の組合せで強い相関を示している。

「複雑さ」と「動的」は視覚的快適因子 2 の「動静と単複」を設問 上分けた項目であるので、正の相関があることは順当であると言え る。各視覚的快適因子は複数の視覚的快適因子と相関性を持つが、 「古さ」と「シュムメトリアの均衡と広がり」「「シュムメトリアの均 衡と広がり」と「対比の強調と力強さ」、「対比の強調と力強さ」と

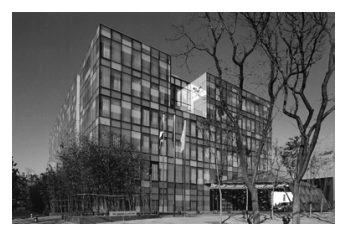

No.C-6

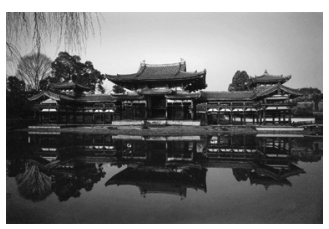

No.C-15

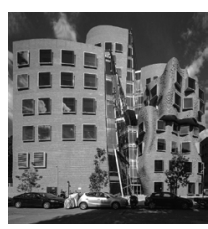

No.C-24
Fig.4 Example photos of the impression evaluation with the Visual comfort factors 視覚的快適因子による印象評価実験の評価対象例

Table 9 Respondor Attributes of Impression evaluation experiment (Common people) 一般回答者の属性

\begin{tabular}{|l|l|r|r|r|r|r|r|r|}
\hline \multicolumn{2}{|c}{ Age 年代 } & $\begin{array}{c}\text { Less } \\
\text { than } \\
20 s\end{array}$ & $20 s$ & $30 s$ & $40 s$ & $50 s$ & $\begin{array}{c}\text { Over } \\
60 s\end{array}$ & $\begin{array}{c}\text { Total } \\
\text { 計 }\end{array}$ \\
\hline \multirow{2}{*}{$\begin{array}{l}\text { Gender } \\
\text { 性別 }\end{array}$} & Male 男性 & 1 & 5 & 3 & 4 & 5 & 1 & 19 \\
\cline { 2 - 10 } $\begin{array}{l}\text { Job } \\
\text { 職種 }\end{array}$ & Oemale 女性 & 4 & 17 & 2 & 4 & 4 & 0 & 31 \\
\cline { 2 - 10 } & Other students その他学生 & 5 & 16 & 0 & 0 & 0 & 0 & 21 \\
\hline \multicolumn{2}{|c|}{ Total 計 } & 0 & 5 & 5 & 7 & 9 & 1 & 27 \\
\hline
\end{tabular}

Table 10 Average of Evalution values of Impression evaluation experiment with Visual comfort factors (Students of Architecture) 視覚的快適因子による印象評価実験結果 各評価対象写真および各設問における平均値（建築学科学生回答者）

\begin{tabular}{|r|r|r|r|r|r|r|r|r|r|r|r|r|r|r|r|r|r|r|r|r|r|r|r|r|r|r|r|r|r|r|r|r|r|r|}
\hline & C-01 & C-02 & C-03 & C-04 & C-05 & C-06 & C-07 & C-08 & C-09 & C-10 & C-11 & C-12 & C-13 & C-14 & C-15 & C-16 & C-17 & C-18 & C-19 & C-20 & C-21 & C-22 & C-23 & C-24 \\
\hline Q1 & 1.18 & 1.16 & 0.25 & 0.04 & 0.85 & 1.33 & 0.96 & 1.44 & 1.65 & 0.69 & 1.44 & -0.15 & 1.62 & 1.15 & 0.82 & 1.84 & 1.51 & 1.58 & 0.22 & 0.71 & 1.76 & 1.35 & 0.96 & 1.80 \\
\hline Q2 & 0.13 & -0.18 & 0.42 & 1.15 & -0.60 & -0.11 & 0.93 & -0.91 & -0.25 & 0.53 & 0.73 & 1.25 & -0.76 & -0.33 & 0.44 & -0.71 & -0.85 & -0.85 & -0.04 & -0.29 & -1.62 & 0.55 & -0.11 & -1.62 \\
\hline Q3 & 0.67 & 1.07 & 0.82 & 0.95 & 0.65 & 0.91 & 0.95 & 0.33 & -0.58 & 0.27 & 0.22 & 1.20 & -0.07 & 0.44 & -0.24 & -1.31 & 0.22 & -0.47 & 0.87 & 0.78 & -1.07 & 0.55 & 0.78 & -1.29 \\
\hline Q4 & -0.56 & 1.73 & -0.82 & -0.42 & 1.05 & 1.40 & -1.38 & 0.16 & -1.16 & -1.56 & 0.45 & -1.04 & 0.27 & 1.35 & -1.45 & -0.11 & -0.53 & -0.62 & 0.55 & 0.84 & -1.22 & -0.71 & -0.40 & -0.91 \\
\hline Q5 & 0.60 & 0.85 & -0.13 & 0.58 & 0.40 & 1.56 & 0.65 & 0.69 & 0.47 & 0.58 & 0.91 & -0.29 & 1.24 & -0.04 & 0.55 & 0.96 & 1.49 & 0.67 & -0.16 & 0.11 & 0.75 & 0.89 & 0.91 & 0.65 \\
\hline Q6 & 1.29 & -1.73 & 0.76 & -0.38 & -1.15 & -1.58 & 1.07 & -1.29 & 0.73 & 1.33 & -1.11 & -0.15 & -1.15 & -0.11 & 1.47 & 1.65 & -1.16 & 0.56 & -0.69 & -1.16 & 1.60 & -1.09 & -0.58 & 1.40 \\
\hline Q7 & 0.71 & 0.27 & 0.47 & 0.22 & 0.71 & 1.05 & 0.27 & 0.40 & 0.18 & 0.22 & 0.02 & -0.02 & 0.09 & 0.71 & -0.42 & 0.62 & 0.75 & 0.22 & -0.40 & -0.04 & 0.22 & -0.27 & 0.62 & 0.24 \\
\hline Q8 & 0.13 & 0.89 & -0.13 & 0.89 & 0.60 & 1.33 & 0.31 & 0.60 & 0.33 & 0.60 & 1.11 & 0.44 & 1.05 & 0.42 & 0.38 & 0.04 & 1.16 & 1.09 & -0.09 & -0.04 & 0.02 & 1.00 & 0.75 & -0.02 \\
\hline Q9 & 0.71 & 1.31 & 0.02 & 0.36 & 1.35 & 1.67 & 0.69 & 1.13 & 0.56 & 0.49 & 0.84 & -0.05 & 1.40 & 1.05 & 0.40 & 1.07 & 1.35 & 0.55 & -0.05 & 0.45 & 0.91 & 0.36 & 1.24 & 0.82 \\
\hline
\end{tabular}

Table 11 Average of Evalution values of Impression evaluation experiment with Visual comfort factors (Students of Architecture)

視覚的快適因子による印象評価実験結果 各評価対象写真および各設問における平均值（一般回答者）

\begin{tabular}{|l|r|r|r|r|r|r|r|r|r|r|r|r|r|r|r|r|r|r|r|r|r|r|r|r|r|r|r|r|r|r|r|r|r|r|}
\hline & C-01 & C-02 & C-03 & C-04 & C-05 & C-06 & C-07 & C-08 & C-09 & C-10 & C-11 & C-12 & C-13 & C-14 & C-15 & C-16 & C-17 & C-18 & C-19 & C-20 & C-21 & C-22 & C-23 & C-24 \\
\hline Q1 & 1.23 & 1.63 & 0.15 & -0.46 & 1.25 & 1.35 & 0.79 & 1.46 & 1.58 & 0.69 & 1.50 & 0.17 & 1.67 & 1.44 & 1.02 & 1.81 & 1.67 & 1.75 & -0.35 & 0.71 & 1.83 & 1.27 & 1.17 & 1.71 \\
\hline Q2 & 0.13 & -0.23 & 0.29 & 1.31 & -0.42 & 0.15 & 1.10 & -0.69 & 0.10 & 0.52 & 0.54 & 1.06 & -0.67 & -0.52 & 0.46 & -0.46 & -0.77 & -0.71 & 0.08 & -0.38 & -1.44 & 0.60 & -0.08 & -1.48 \\
\hline Q3 & 0.44 & 0.71 & 0.71 & 0.96 & 0.79 & 1.15 & 0.94 & 0.27 & -0.46 & 0.15 & 0.19 & 0.88 & -0.08 & 0.17 & 0.00 & -0.83 & 0.04 & -0.67 & 0.60 & 0.54 & -1.29 & 0.29 & 0.71 & -1.38 \\
\hline Q4 & -1.13 & 1.81 & -0.92 & -0.83 & 1.23 & 1.65 & -1.04 & 0.52 & -1.08 & -1.35 & 0.69 & -0.96 & 1.08 & 1.52 & -0.90 & -0.17 & 0.29 & 0.27 & 0.25 & 0.58 & -1.25 & -0.60 & 0.13 & -0.65 \\
\hline Q5 & 0.65 & 1.35 & -0.23 & 0.40 & 0.60 & 1.54 & 0.27 & 0.79 & 0.81 & 0.29 & 1.10 & -0.48 & 1.33 & 0.38 & 0.42 & 1.08 & 1.48 & 0.96 & -0.50 & -0.13 & 0.88 & 0.52 & 1.15 & 0.81 \\
\hline Q6 & 1.19 & -1.42 & 1.00 & -0.52 & -1.17 & -1.25 & 0.75 & -1.29 & 0.88 & 0.71 & -1.06 & -0.29 & -0.98 & 0.02 & 1.31 & 1.46 & -1.10 & 0.35 & -0.65 & -1.21 & 1.50 & -1.08 & -0.73 & 1.54 \\
\hline Q7 & 0.08 & 0.42 & 0.38 & -0.44 & 1.08 & 1.10 & 0.13 & 0.38 & -0.21 & -0.54 & -0.19 & -0.46 & 0.40 & 0.73 & -0.27 & -0.29 & 0.63 & -0.15 & -0.23 & -0.06 & -0.65 & -0.44 & 0.69 & -0.63 \\
\hline Q8 & -0.17 & 0.92 & -0.25 & 0.69 & 0.71 & 1.63 & 0.29 & 0.65 & -0.04 & 0.23 & 1.04 & 0.19 & 0.73 & 0.38 & 0.48 & -0.25 & 1.31 & 0.79 & -0.33 & -0.10 & -0.44 & 0.83 & 0.92 & -0.40 \\
\hline Q9 & 0.42 & 1.42 & 0.02 & -0.08 & 1.58 & 1.85 & 0.15 & 1.25 & 0.17 & -0.19 & 0.92 & -0.38 & 1.52 & 1.25 & 0.23 & 0.40 & 1.58 & 0.67 & -0.33 & 0.00 & 0.52 & -0.21 & 1.54 & 0.21 \\
\hline
\end{tabular}

Table $12 \mathrm{t}$ Test of Impression evaluation experiment with Visual comfort factors $\mathrm{t}$ 検定結果

\begin{tabular}{|l|l|l|l|l|l|l|l|l|l|l|l|l|l|l|l|l|l|l|l|l|l|l|l|l|l|l|l|l|l}
\hline & C-01 & C-02 & C-03 & C-04 & C-05 & C-06 & C-07 & C-08 & C-09 & C-10 & C-11 & C-12 & C-13 & C-14 & C-15 & C-16 & C-17 & C-18 & C-19 & C-20 & C-21 & C-22 & C-23 & C-24 \\
\hline
\end{tabular}

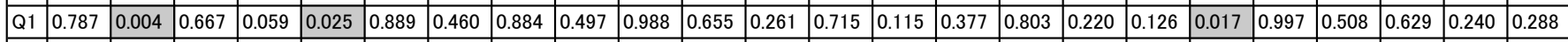

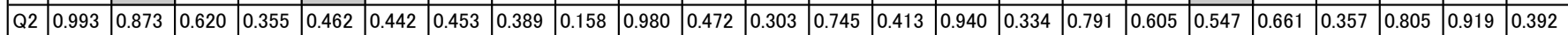
\begin{tabular}{l|l|l|l|l|l|l|l|l|l|l|l|l|l|l|l|l|l|l|l|l|l|l|l|l|l}
\hline Q3 & 0.300 & 0.141 & 0.608 & 0.946 & 0.540 & 0.342 & 0.971 & 0.810 & 0.596 & 0.581 & 0.906 & 0.106 & 0.969 & 0.289 & 0.383 & 0.056 & 0.560 & 0.422 & 0.122 & 0.245 & 0.314 & 0.241 & 0.706 & 0.622 \\
\hline
\end{tabular}

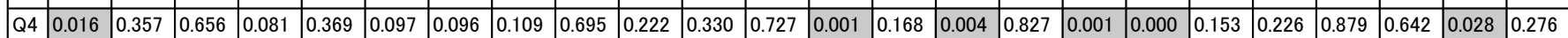
\begin{tabular}{|l|l|l|l|l|l|l|l|l|l|l|l|l|l|l|l|l|l|l|l|l|l|l|l|l|l}
\hline Q5 & 0.841 & 0.013 & 0.664 & 0.454 & 0.358 & 0.860 & 0.099 & 0.620 & 0.116 & 0.201 & 0.300 & 0.447 & 0.560 & 0.064 & 0.557 & 0.578 & 0.937 & 0.138 & 0.111 & 0.316 & 0.598 & 0.085 & 0.224 & 0.463 \\
\hline
\end{tabular} \begin{tabular}{l|l|l|l|l|l|l|l|l|l|l|l|l|l|l|l|l|l|l|l|l|l|l|l|l|l|l|}
\hline Q6 & 0.559 & 0.095 & 0.168 & 0.380 & 0.904 & 0.118 & 0.117 & 0.997 & 0.496 & 0.004 & 0.827 & 0.496 & 0.402 & 0.531 & 0.326 & 0.166 & 0.796 & 0.312 & 0.777 & 0.805 & 0.466 & 0.965 & 0.453 & 0.308 \\
\hline
\end{tabular} \begin{tabular}{l|l|l|l|l|l|l|l|l|l|l|l|l|l|l|l|l|l|l|l|l|l|l|l|l}
\hline Q7 & 0.009 & 0.575 & 0.666 & 0.002 & 0.065 & 0.809 & 0.504 & 0.899 & 0.048 & 0.001 & 0.354 & 0.053 & 0.167 & 0.913 & 0.532 & 0.000 & 0.575 & 0.062 & 0.393 & 0.907 & 0.001 & 0.443 & 0.706 & 0.000 \\
\hline
\end{tabular}

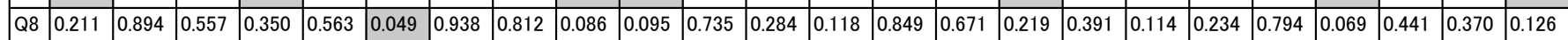

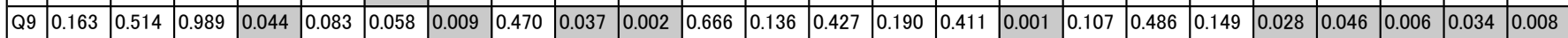
Less than 0.05 
「特徵的な形体」、「特徽的な形体」と「動的」、「動的」と「新しさ」 で相関性がみられ、「新しさ」と「古さ」の相反する視覚的快適要素 が数珠繋ぎ状に繋がる様な構造を形成している。これら相関の複雑 さが視覚的快適性評価の難しさに関係していると推察される。前節 の結果と併せて考えると、視覚的快適性評価基準を探る上で、今後、 視覚的快適因子の評価值及び視覚的快適因子同士の組合せパタン等 の検証が必要であると考える。また、建築学科学生と一般回答者は ほぼ同様の傾向を示しているが、建築学科学生に比べ、一般回答者 では「自然人工と風合い」が「清明さ」「シュムメトリアの均衡と広 がり」と相関が高く、自然に対して清明さや調和を感じていること が窥える。また、相関性の低い（相関係数の絶対值が 0.1 以下）も のをみると、建築学科学生は 5 組、一般回答者は 1 組であり、建築 学科学生の方が評価の独立性が高いことが窥える。これらは建築教 育による効果と捉えられるが、年齢や世代による傾向も考えられ、 今後詳細な検証が必要である。

\section{5 視覚的快適性の評価構造}

本節では前節までの結果を踏まえ、視覚的快適性の評価構造につ いての考察を行う。各視覚的快適因子間の相関関係を Fig. 6 に示寸。

「動静と単複」及び「新古」は相反する対立概念によって構成され、 相対概念として括られた因子である。「複雑」と「新しさ」は「動的」 を介して関係性を持ち、「均質」と「古さ」は「静的」を介して関係 性を持つ。また、「複雑」と「動的」は「特徴的な形体」と、「古さ」 は「シュムメトリアの均衡と広がり」と関係性を持ち、「特徴的な形 体」と「シュムメトリアの均衡と広がり」は「対比の強調と力強さ」 を介して関係性を持つ。これらは内部に対立概念注8) を含みながら も繞ることのできる回路的構造を形成しており、単に各視覚的快適 因子の個別の強弱だけでは視覚的快適性の評価が決定されないと推
Table 13 Correlation between Visual comfort factors (Students of Architecture) 視覚的快適因子の相関（建築学科学生回答者）

\begin{tabular}{|c|c|c|c|c|c|c|c|c|}
\hline & $\begin{array}{l}\text { Distinguishing } \\
\text { form } \\
\text { 特徵的な } \\
\text { 形体 }\end{array}$ & \begin{tabular}{|c} 
Homogeneous \\
$\uparrow \downarrow$ \\
Complexity \\
均質(+) \\
$\uparrow \downarrow$ \\
複雑( $(-)$ \\
\end{tabular} & \begin{tabular}{|c|} 
Static \\
$\uparrow \downarrow$ \\
Dynamism \\
静的(+) \\
$\uparrow \downarrow$ \\
動的(-) \\
\end{tabular} & \begin{tabular}{|c} 
Nature \\
Texture \\
自 \\
然合い \\
\end{tabular} & \begin{tabular}{|c|} 
Emphasis \\
by contrast \\
Strength \\
対比の強調 \\
力強さ
\end{tabular} & $\begin{array}{c}\text { New } \\
\uparrow \downarrow \\
\text { Age-Old } \\
\text { 新しささ(+) } \\
\uparrow \downarrow \\
\text { 古さ(-) } \\
\text { 古 }\end{array}$ & \begin{tabular}{|c|}
$\begin{array}{c}\text { Cleanliness } \\
\text { Clarity }\end{array}$ \\
清明さ
\end{tabular} & \begin{tabular}{|c|} 
Repetition \\
Symmetry \\
Harmony \\
反復性 \\
対称性 \\
調和 \\
\end{tabular} \\
\hline $\begin{array}{l}\text { Distinguishing form } \\
\text { 特徵的な形体 }\end{array}$ & 1.00 & & & & & & & \\
\hline $\begin{array}{l}\text { Complexity } \Leftrightarrow \text { Homogeneous } \\
\text { 複狳( }(-) \Leftrightarrow \text { 均質 }(+)\end{array}$ & -0.71 & 1.00 & & & & & & \\
\hline $\begin{array}{l}\text { Dynamism } \Leftrightarrow \text { Static } \\
\text { 動的 }(-) \Leftrightarrow \Leftrightarrow \text { 静的 }(+)\end{array}$ & -0.72 & 0.67 & 1.00 & & & & & \\
\hline $\begin{array}{l}\text { Nature, Texture } \\
\text { 自然、風合い }\end{array}$ & 0.04 & -0.17 & 0.35 & 1.00 & & & & \\
\hline $\begin{array}{l}\text { Emphasis by contrast, } \\
\text { Strength } \\
\text { 対比の強調、力強さ }\end{array}$ & 0.68 & -0.33 & -0.37 & -0.07 & 1.00 & & & \\
\hline $\begin{array}{l}\text { Age-Old } \Leftrightarrow \text { New } \\
\text { 古さ }(-) \Leftrightarrow \text { 新しさ(+) }\end{array}$ & 0.11 & -0.07 & -0.57 & -0.73 & -0.12 & 1.00 & & \\
\hline $\begin{array}{l}\text { Cleanliness, Clarity } \\
\text { 清明さ }\end{array}$ & 0.27 & -0.28 & 0.04 & 0.31 & 0.20 & -0.07 & 1.00 & \\
\hline $\begin{array}{l}\text { Repetition, Symmetry, } \\
\text { Harmony } \\
\text { 反復性、対称性、調和 }\end{array}$ & 0.20 & 0.13 & 0.23 & 0.27 & 0.55 & -0.60 & 0.19 & 1.00 \\
\hline
\end{tabular}

Table 14 Correlation between Visual comfort factors (Common People) 視覚的快適因子の相関（一般回答者）

\begin{tabular}{|c|c|c|c|c|c|c|c|c|}
\hline & $\begin{array}{l}\text { Distinguishing } \\
\text { form } \\
\text { 特徴的な } \\
\text { 形体 }\end{array}$ & \begin{tabular}{|c|c|} 
Homogeneous & $\downarrow$ \\
$\uparrow \downarrow$ \\
Complexity \\
均質(+) \\
$\uparrow \downarrow$ \\
複雑( $(-)$ \\
\end{tabular} & \begin{tabular}{|c|} 
Static \\
$\uparrow \downarrow$ \\
$\downarrow 1$ \\
Dynamism \\
静的(+) \\
$\uparrow \downarrow$ \\
動的(-) \\
\end{tabular} & 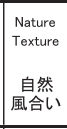 & 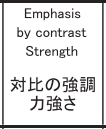 & 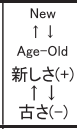 & \begin{tabular}{|c|}
$\begin{array}{c}\text { Cleanliness } \\
\text { Clarity }\end{array}$ \\
\\
清明さ
\end{tabular} & \begin{tabular}{|c|} 
Repetition \\
Symmetry \\
Harmony \\
反復性 \\
对称性 \\
調和 \\
\end{tabular} \\
\hline $\begin{array}{l}\text { Distinguishing form } \\
\text { 特徵的な形体 }\end{array}$ & 1.00 & & & & & & & \\
\hline $\begin{array}{l}\text { Complexity } \Leftrightarrow \text { Homogeneous } \\
\text { 複秛 }(-) \Leftrightarrow \text { 均質 }(+)\end{array}$ & -0.67 & 1.00 & & & & & & \\
\hline $\begin{array}{l}\text { Dynamism } \Leftrightarrow \text { Static } \\
\text { 動的 }(-) \Leftrightarrow \text { 静的( }(+)\end{array}$ & -0.60 & 0.69 & 1.00 & & & & & \\
\hline $\begin{array}{l}\text { Nature, Texture } \\
\text { 自然、風合い }\end{array}$ & 0.31 & -0.31 & 0.26 & 1.00 & & & & \\
\hline $\begin{array}{l}\text { Emphasis by contrast, } \\
\text { Strength } \\
\text { 対比の強調、万強さ }\end{array}$ & 0.78 & -0.43 & -0.29 & 0.42 & 1.00 & & & \\
\hline 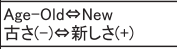 & 0.08 & -0.11 & -0.58 & -0.71 & -0.19 & 1.00 & & \\
\hline $\begin{array}{l}\text { Cleanliness, Clarity } \\
\text { 清明さ }\end{array}$ & 0.19 & -0.14 & 0.49 & 0.71 & 0.36 & -0.51 & 1.00 & \\
\hline $\begin{array}{l}\text { Repetition, Symmetry, } \\
\text { Harmony } \\
\text { 反復性、対称性、調和 }\end{array}$ & 0.22 & 0.17 & 0.42 & 0.57 & 0.58 & -0.70 & 0.57 & 1.00 \\
\hline
\end{tabular}

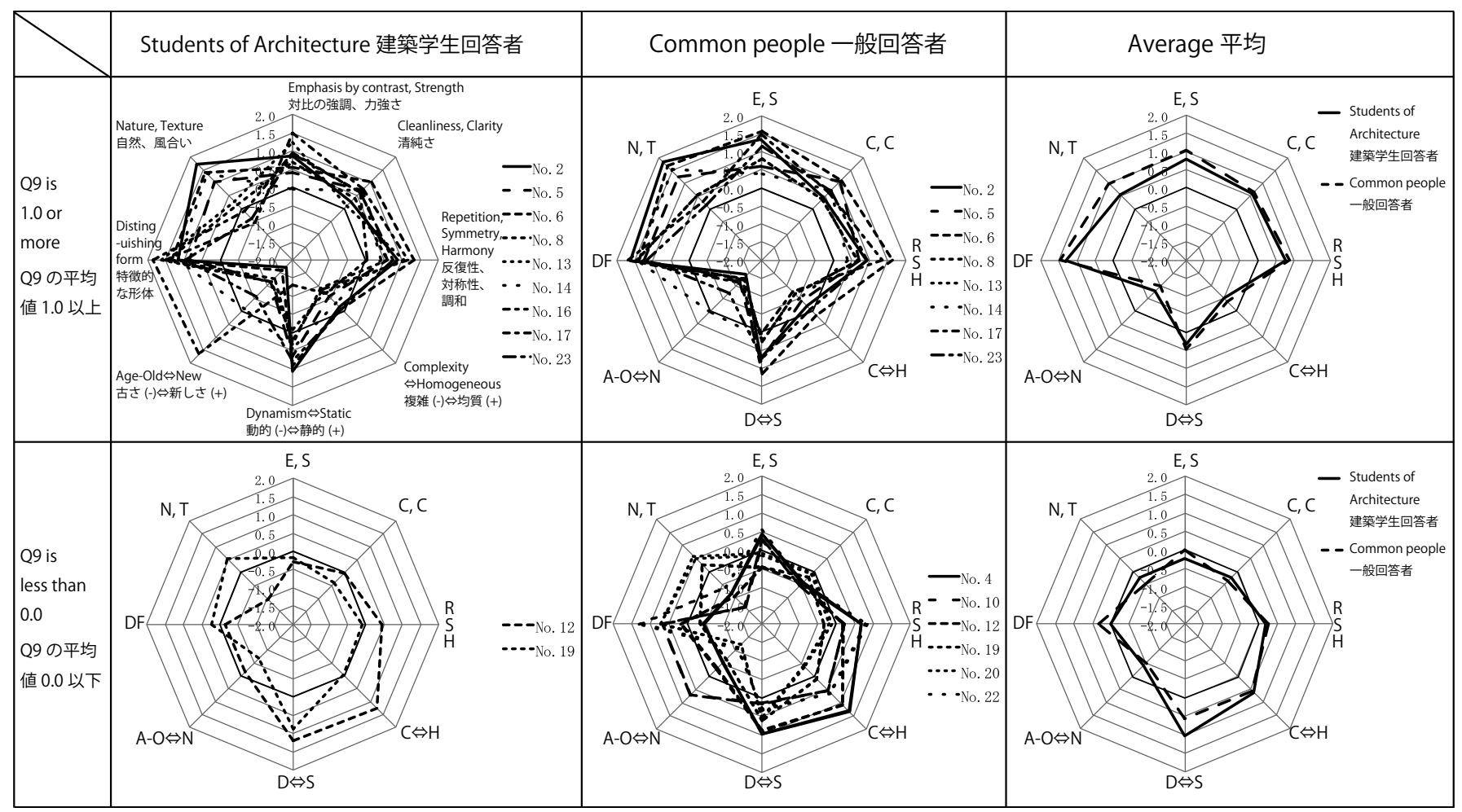

Fig.5 Average of Evaluation values of Visual comfort factors whose value of Q9 is 1.0 or more and less than 0.0

09 の平均值が 1.0 以上および 0.0 以下の各視覚的快適因子の評価値 


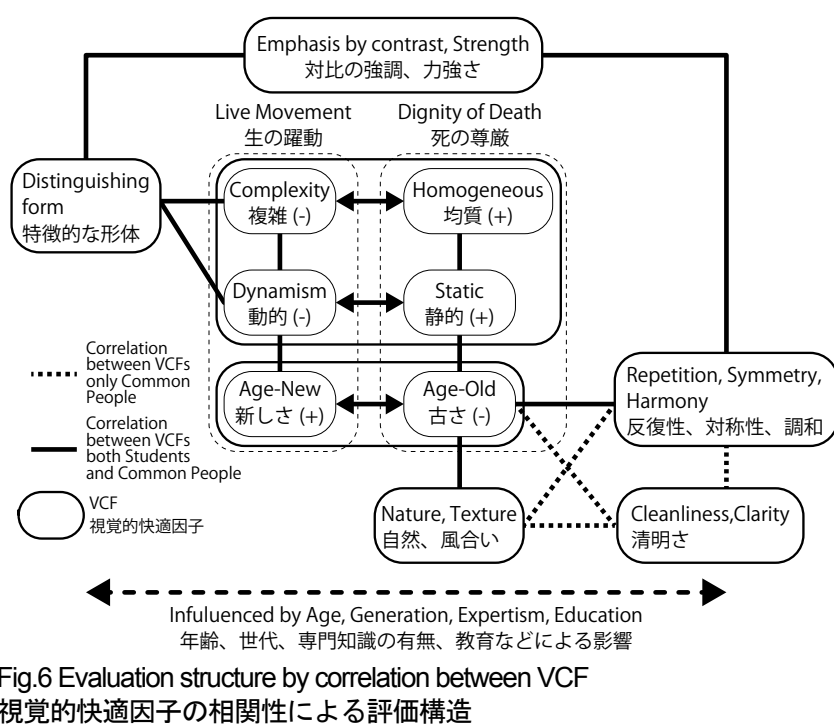

察される。視覚的快適要素の組合せに拠っては、視覚的快適要素か ら受ける印象が相殺されて視覚的快適性の評価が下がる可能性が考 えられる。また 5 章 3 節で述べたように、各視覚的快適因子の評価 值が 0.0 に近くなると視覚的快適性の評価は低くなる可能性があり、 中途半端に各因子を満遍なく感じるよりも、ある因子に特化して強 く感じる方が視覚的快適性の評価が高くなる可能性も考えられる。 これらについては、今後、各視覚的快適要素別に程度による感受性 の差異や要素の組合せによる効果等の検証を行う予定である。

以上の関倸性は建築学科学生回答者及び一般回答者に共通してい るが、「自然、風合い」及び「清明さ」と「古さ」及び「シュムメト リアの均衡と広がり」における関係性は、一般回答者にのみ形成さ れている。建築 (専門知識) 教育の有無或いは年齢や世代による影 響が考えられる。特に年齢や世代による序列は、評価構造内部の対 立概念に対応した軸となるのではないかと推察しており、今後、被 験者の属性別実験を行い検証したいと考えている。

\section{6 結論}

以上、建築学科学生を対象に、建築における視覚的快適性の構成 要素を抽出するためのアンケート調査を行い、51の視覚的快適要素 と 27 の要素グループを抽出した。また、要素グループを用いた印 象評価実験を行い、因子分析から 7 つ視覚的快適因子を導出した。 更に、建築学科学生と一般回答者に対して、視覚的快適因子を用い た印象評価実験を行い、建築学科学生と一般回答者とで、視覚的快 適性の評価の傾向は概社一致しているが、「自然人工と風合い、「清 明さ」「美しさを感じるか」に関して、建築教育がこれらの感受性に 影響する可能性および評価の独立性を高める可能性を示唆した。ま た、視覚的快適因子の相関性から、複数の視覚的快適因子が相関性 を持ち、それらには相反する視覚的快適因子が含まれることを示し た。更に視覚的快適性の評価構造として、内部に対立概念を含みな がらも繞ることのできる回路的構造を形成していることを示した。

本稿では建築における視覚的快適性の要因を導出し、それらの相 関性から評価構造の一端を明らかにした。しかし、前述のように評 価基準を明らかにするには各構成要素における程度による感受性の 差異や各構成要素の組合せによる評価成立条件の検証等、詳細な解
明が必要である。また、本研究の大きな目的としては、得られた知 見を設計教育に活用していくことにあるが、単純に構成要素を使う ことで美しい建築が生まれるとは考えていない。判断できることと 作り出せることは別物である。美しい建築の創出には構成要素の程 度や組合せなど使い方が重要であり、そのための設計教育方法の開 発も必要である。

\section{謝辞}

本稿は鹿児島大学大学院見地学専攻 安東迪代氏の 2016 年度修士 論文 (「因子分析を用いた建築写真における視覚的快適性の評価基準 に関する研究」）を基に分析を加え、加筆修正行ったものである。

注

注 1）井上充夫氏は、「建築の実用的な面や技術的な面については、すでに話し方 や考え方の基礎が確立されているが、建築の美的な面や芸術的な面について はそれが出来ていない。」と指摘している。参考文献 2) p. 9

注 2）井上充夫氏は、美的判断は主観的、直観的なもので「無合理」であるとし、 また美的判断の主観は一定不変でないと述べているが、同時に、他人に説明 でき、共感を求めることができるものとしている。本研究では、美的判断基 準が説明可能であることから無合理ではなく、評価構造を有する事象である との立場を取り、その解明を試みるものである。参考文献 4)pp. 8-11

注 3）「美」や「美しさ」の定義は難しい。例えば、本稿で美的評価項目（要素） として抽出された「面白さ」や「珍しさ」は「美」や「美しさ」を狭義に捉 えてしまうとそぐわないように思われる。この様な評価項目も含めて美的評 価構造を扱うには、美的評価の一部を視覚的な快適性と捉えた方が撂㽬が少 なくなると考元、本稿の文中では「視覚的快適性」という用語を用いる。ただし、 調查や実験では、視覚的快適性という用語は一般的では無いため、被験者に 理解しやすい様に「美しい」という用語を用いて実施している。

注 4) 建築は 3 次元の物体であり、人が含まれる空間である。視覚的快適性を判断 する写真は 2 次元であるため、情報の限定や写真自体による影響も考えられ るが、写真の構図など、写真自体が持つ属性もその様な写真を撮ることが出 来る形態要素を建築が持っているのであり、本研究では視覚的快適性を構成 する要素と成り得ると考えている。

注 5）回答語の中には写真の構図に関する記述もみられた。これらは写真の実在に おける視觉的快適性と考えられるが、構図による2 次元（絵画）的手法は立 面計画や配置計画等、建築設計や空間デザインに援用できる可能性が考えら れる。本研究は設計教育への展開も視野に入れているため、上記注 4 の考え と合わせて判断し、本稿では除外せずに「写真の構図」と明示して含めるこ ととした。

注 6) 写真の選択は、建築学科学生 9 名による合議制により行った。

注 7) 建築雑誌や建築写真集に揭載されている写真は、建築が写真のモチーフであ り、建築を美しく見せようとする意図があると考えられ、因子分析から得た 7 つの因子の評価軸の検証ができると考える。選出方法は、11 冊の書籍（「新建 築臨時増刊 建築 20 世紀 PART1, PART2」,「GA DOCUMENT 105, 106, 131, 133」, 「JA The Japan Architect 80」, 「日本木造遺産 千年の建築を旅する」, 「写真紀行 ヨーロッパ古城物語」，「世界の教会」「世界の寺院」）から時代や西洋と東洋 の写真を十数枚ずつ偏りなく集め、それらから 4 枚ずつ無作為に選出し、計 24 枚をアンケート写真とした。評価対象の建築写真は、建築の外観がほぼ収 まっているカラー写真とした。

注 8) 本稿では、これらの対立概念の括りを「生の躍動」と「死の尊綮」と命名し た (Fig. 6)。「死の尊厳」に含まれる「古い」は「自然、風合い」との相関が みられ、「自然」は「生」とも考えられるが、回答写真に写っている「自然」 の多くは空、水面、森林などであり、ヒューマンスケールを超えた存在性が「生 の躍動」よりも「死の尊厳」を印象付けるのではないかと考光る。また「生」 「死」は対象物の状態を示寸属性的表現ではなく、感受者側における比喻的表 現である。

\section{参考文献}

1) MORITA Kei-ichi: Architectural theory, Tokai University, 1994.2 森田慶一 : 建築論, 東海大学出版会, 1994.2 
2) INOUE Mitsuo: History of architectural aesthetics, Kajima-publishing, 2000.3 井上充夫 : 建築美論の歩み, 鹿島出版会, 2000.3

3) TAKAHASHI Hironobu, OI Naoyuki: THE AESTHETIC SENSE OF VALUES AND EVALUATION STRUCTURE IN INTERIOR SPACE, Journal of Architecture and Planning (Transactions of AIJ), No.615, pp. 59-64, 2007.5

4) INOUE Mitsuo: The world of architectural beauty, Kajima-publishing, 1981.12 井上充夫 : 建築美の世界, 鹿島出版会, 1981.12

5) TAKAHASHI Hironobu, OI Naoyuki: CREATION OF THE CHECK LIST OF THE BEAUTY IN INTERIOR DESIGN SPACE, AIJ Journal of Technology and Design, No. 26, pp. 613$616,2007.3$

6) ONO Yasushi : Aesthetetic Preference of Architecture and Personarity : by Multi Dimensionnal Analysis Method, Proceedings of annual research meeting Chugoku Chapter, AIJ, No. 20, pp. 441-444, 1997. 11

7) SHIOZAKI Taishin, OKUYAMA Shin-ichi: DUAL CONCEPTS IN DESIGN THEORIES BY CONTEMPORARY JAPANESE ARCHITECTS, Journal of Architecture and Planning (Transactions of AIJ), No.610, pp. 79-86, 2006. 12

8) SHIOZAKI Taishin, OKUYAMA Shin-ichi: ORIGINAL PHRASES INCLUDING 'SPACE' IN DESIGN THEORIES BY CONTEMPORARY JAPANESE ARCHITECTS, Journal of Architecture and Planning (Transactions of AIJ), No.633, pp. 2333-2340, 2008. 11

9) SHIOZAKI Taishin, YAMAMOTO Yoichiro, OKUYAMA Shin-ichi: DESIGN CONCEPT OF SCALE IN DESIGN THEORIES BY CONTEMPORARY JAPANESE ARCHITECTS, Journal of Architecture and Planning (Transactions of AIJ), No.651, pp. 1087-1096, 2010.5

10) KITAGAWA Keisuke, NAITO Takuya, TERADA Kyohei: POLYSEMY OF LIGHT IN TEXT DESCRIPTION OF BUILDINGS, Journal of Architecture and Planning (Transactions of AIJ), No. 680, pp. 2345-2353, 2012. 10

11) KITAGAWA Keisuke, YONEZAWA Takashi, OI Ryo: POLYSEMY OF TRANSPARENCY IN TEXT DESCRIPTION OF BUILDINGS, Journal of Architecture and Planning (Transactions of AIJ), No. 686, pp. 791-799, 2013.4

12) KITAGAWA Keisuke, YONEZAWA Takashi, YAMANASHI Takemi: POLYSEMY OF WHITE IN TEXT DESCRIPTION OF BUILDINGS, Journal of Architecture and Planning (Transactions of AIJ), No.698, pp.923-932, 2014.4

13) KITAGaWA Keisuke, NAKAZAWA Shinpei: POLYMORPH OF “TANOSHISA" IN TEXT DESCRIPTION OF BUILDING, Journal of Architecture and Planning (Transactions of AIJ), No. 738, pp. 1925-1933, 2017.8

14) INOUE Mitsuo: Emotional Aspects of Architectural Design, Proceedings of annual research meeting Kanto Chapter, AIJ, No.11, pp. 1-4, 1951. 5

15) INOUE Mitsuo: Proposal on Architectural Art, Journal of Architecture and Building Science, No. 831 pp. 45-50, 1956.2

16) ITO Gyo: Study on what forms the basis of aesthetic evaluation, Proceedings of annual research meeting Kyushu Chapter, AIJ, No. 14, pp. 77$81,1965.2$

17) TAKAHASHI Hironobu, OI Naoyuki: Research on the concept of beauty of today's Japanese people : Impression analysis of traditional architectural space, Summaries of Technical Papers of Annual Meeting, Architectural Institute of Japan, D-1, pp. 851-852, 2003.7 高橋浩伸, 大井尚行 : 現代日本人の美の概念に関する研究 一伝統的建築空間 における印象評価分析一, 日本建築学会大会学術講演梗概集, D-1, pp. 851852, 2003.7

18) TAKAHASHI Hironobu, OI Naoyuki: RESEARCH ON "AIMAI" AS A CONCEPT THE BEAUTY, Proceedings of annual research meeting Kyushu Chapter, AIJ, No. 43, pp. 34-40, 2004. 3

19) KAMATA Ryota, NAKAMURA Shigeharu, KANEKO Kazuhito: Research on Evaluation System for Aesthetic Pose in case of Appearance of High Rise Building Differed in Exterior Texture, Summaries of Technical Papers of Annual Meeting, Architectural Institute of Japan, A-1, pp. 227-228, 2008.7 鎌田亮太，中村成春，金子和人：外装テクスチャの異なる高層建築外観を事 例とした美的姿勢評価システムに関する基礎的研究, 日本建築学会大会学術講 演梗概集 , A-1, pp. 227-228, 2008.7

20) KAMATA Ryota, NAKAMURA Shigeharu: Basic Research on Evaluation System for Aesthetic Pose in case of Photo Image, Summaries of Technical Papers of Annual Meeting, Architectural Institute of Japan, A-1, pp. 1003-1004, 2009.7 鎌田亮太，中村成春 : 写真 画像を利用した美的姿勢評価システムに関する基 礎的研究, 日本建築学会大会学術講演梗概集, A-1, pp. 1003-1004, 2009.7

21) ANDO Michiyo, SHIBATA Akihiro: A basic study on the evaluation standard of visual comfort in architectural photography, Proceedings of annual research meeting Kyushu Chapter, AIJ, No. 54, pp. 641-644, 2015.3

22) SHIBATA Akihiro, YUTANI Chika, KORENAGA Miki, et al: FACADE DESIGN IN RESIDENTIAL WORKS OF KIYOSI SEIKE FOCUSING ON ELEMENTS AND INTERIOR USE, Journal of Architecture and Planning (Transactions of AIJ), No.609, pp. 201208, 2006. 11

23) SHIBATA Akihiro, YOSHIMOTO Kotaro, FUCHU Takuya, KORENAGA Miki: FACADE DESIGN IN NONRESIDENTIAL WORKS OF KIYOSI SEIKE FOCUSING ON THE RELATIONSHIP BETWEEN THE EXPRESSION OF BEAMS AND COLUMNS AND "MA" , Journal of Architecture and Planning (Transactions of AIJ), No.630, pp. 1833-1838, 2008.8

24) SHIBATA Akihiro, KANEKO Shinya, KORENAGA Miki, et al: FACADE DESIGN IN WORKS OF KIYOSI SEIKE FOCUSING ON THE RELATIONSHIP BETWEEN THE PROPORTION OF WINDOWS, FENESTRATION AND THE EXTERNAL FROM OF ELEVATION, Journal of Architecture and Planning (Transactions of AIJ), No. 651, pp. 1293-1301, 2010. 5

25) KOGA Takaaki, TAKA Akihiko, MUNAKATA Jun, et al: PARTICIPATORY RESEARCH OF TOWNSCAPE, USING "CAPTION EVALUATION METHOD", Journal of Architecture, Planning and Environmental Engineering (Transactions of AIJ), No.517, pp. 79-84, 1999.3

26) KOJIMA Takaya, KOGA Takaaki, MUNAKATA Jun, et al: MULTIVARIATE ANALYSIS ON VERBAL DATA OF "CAPTION EVALUATION METHOD", Journal of Architecture, Planning and Environmental Engineering (Transactions of AIJ), No. 560, pp. $51-58,2002.10$

27) IWASAKI Yukiko, OI Naoyuki: A study about cityscape evaluation by "CAPTION EVALUATION METHOD", Proceedings of annual research meeting Kyushu Chapter, AIJ, No. 39, pp. 21-24, 2000.3

28) James J. Gibson: The Ecological Approach to Visual Perception, SAIENSU-SHA Co.,Ltd. (Translated by KOZAKI Takashi et al), 1986.3 J. J. ギブソン（古崎 敬 翻訳）：生態学的視覚論, サイエンス社. 1986.3 


\title{
A STUDY ABOUT THE EVALUATION CRITERIA OF VISUAL COMFORT ON ARCHITECTURE BY ARCHITECTURAL PICTURES
}

\author{
Akihiro SHIBATA*1 \\ ${ }^{* 1}$ Assoc. Prof., Dept. of Architecture and Architectural Engineering, Faculty of Engineering, Kagoshima University
}

This study is intended to clarify the Evaluation Criteria of Visual Comfort on architecture by architectural pictures. At first, we collect examples of architectural pictures that 57 students in architectural department feel visual comfort and the answers why they feel so. We have gotten 171 pictures and 381 answers as verbal data described simply by free terms. 450 keywords are extracted from the answers, and they are classified according to similarity by Affinity Diagram. As the result of classification, 27 groups have been defined as the Evaluation Criteria of Visual Comfort. "Colorful" is the most number of keywords, "Nature" is the second, "Contrast of Light and Dark" is the third, and after the forth is "Expression of Emphasis", "Forceful", "Harmony", "Depth, Perspective", "Homogeneous, Complex". The average of the number of the answers per picture is 2.23. But we can find others of the Evaluation Criteria of Visual Comfort in the same picture. So, we have confirmed all pictures whether each keywords applies. As the result, the average increases to 8.53 .

Next, we have conducted the impression evaluation experiment using the Semantic Differential method (5 degrees) on the 27 groups of the Evaluation Criteria of Visual Comfort to 58 students in architectural department. As the experimental result, the average of the number of the Evaluation Criteria that Visual Comfort is felt per picture is 5.42. This average is more than the former average. And we applied factor analysis on the experimental results. 7 factors following have been derived from the relationship between 27 groups of the Evaluation Criteria of Visual Comfort. Factor1: Distinguishing form, Factor2: Homogeneous - Complex \& Static - Dynamic, Factor3: Nature - Artifact \& Texture, Factor4: Emphasis by contrast \& Forceful, Factor5: New - Aged-old, Factor6: Cleanliness \& Clarity, Factor7: Repetition, Symmetry \& Harmony.

Furthermore, to confirm the generality of the evaluation structure, we have conducted the impression evaluation experiment with the 7 factors to architectural students and common people. The results are following: (1) The tendency for the evaluation of visual comfort is similar between architectural students and general questionee, however it suggested that architectural education might affect the Evaluation Criteria of Visual Comfort about Factor3, Factor6 and sensitivity of beauty. (2) The correlation of Visual Comfort Factors indicates that the relationship between visual comfort factors contained contradictory, as Factor1 is correlated with Factor7 and "New" by intermediating factor but Factor7 is correlated with "Aged-old". (3) The correlation of Visual Comfort Factors indicates that the evaluation structure of Visual Comfort Factors is a circuit system. It is linked by Factor4 that intermediates between Factor 1 and Factor7 though it includes contradictory elements in Factor2 and Factor5. The contradictory elements in Factor2 and Factor5 are "Complex, Dynamic, New" and "Homogeneous, Static, Aged-old". These may be related to image of "Life" and I call the former "Live movement" and the latter "Dignity of Death". (4) The correlation between Factor3, Factor5, Factor6 and Factor7 is only indicated by common people. This tendency may be influenced by not only the architectural education but also age and generation. 